\title{
Bacterial production along a river-to-ocean continuum in central Chile: implications for organic matter cycling
}

\author{
Cristian A. Vargas ${ }^{1, *}$, Loretto Arriagada ${ }^{1}$, Marcus Sobarzo $^{2}$, Paulina Y. Contreras ${ }^{1}$, \\ Gonzalo Saldías ${ }^{2,3}$ \\ ${ }^{1}$ Aquatic System Unit, Environmental Sciences Center EULA Chile, Universidad de Concepción, Concepción, Chile \\ ${ }^{2}$ Department of Oceanography, Universidad de Concepción, Concepción, Chile \\ ${ }^{3}$ Present address: College of Oceanic and Atmospheric Sciences, Oregon State University, Corvallis, Oregon 97331-5503, USA
}

\begin{abstract}
We examined how variation in bacterial abundance (BA), biomass (BB), and production (BP) along a river-ocean continuum might be related to the large heterogeneity of potential controlling factors upon different scenarios of river flow and coastal upwelling in the adjacent ocean. Between late July 2010 and January 2011, representing winter, spring, and summer conditions, we sampled 7 stations along the Biobío River in Central Chile $\left(36^{\circ} \mathrm{S}\right)$, and almost simultaneously, the adjacent ocean. BP along the river ranged from 3.1 to $168.4 \mathrm{\mu g} \mathrm{Cl}^{-1} \mathrm{~d}^{-1}$, with the highest values associated with the more anthropogenically influenced areas, where highest nitrate $\left(\mathrm{NO}_{3}{ }^{-}\right)$ and dissolved organic carbon (DOC) were also observed. High bacterial growth rates (BGR) were observed along the river, but BA and BB were relatively low in comparison to the coastal ocean, probably associated with a strong top-down control along the river. The most isotopically depleted DOC $\left(\delta^{13} \mathrm{C}-\mathrm{DOC},-30\right.$ to $\left.-33 \%\right)$ was also observed in anthropogenically influenced areas, but unequivocal signatures suggest that DOC represented many different terrestrial sources with different isotopic composition, which supported $\mathrm{BP}$ along the river. BP estimates along the river plume ranged from 0.7 to $81 \mu \mathrm{g} \mathrm{C} \mathrm{l}^{-1} \mathrm{~d}^{-1}$. The $\delta^{13} \mathrm{C}$-DOC distribution along the river-ocean continuum indicated that riverine flux of organic matter dramatically influenced the composition of DOC in this coastal upwelling area. During summer - when river flow was extremely low, coastal upwelling events were recurrent, and high chlorophyll a was enhanced — riverine DOC might not have contributed significantly to carbon pools in this coastal area. The temporal scale of river plume impacts on BP might vary with the magnitude of river discharge and wind-induced coastal upwelling events.
\end{abstract}

KEY WORDS: Bacterioplankton $\cdot$ Bacterial production $\cdot$ River plume $\cdot$ Coastal upwelling

\section{INTRODUCTION}

Rivers play a significant role linking the carbon cycles of the continent and the oceans (Cole et al. 2007). They transport an estimated amount of $4 \times$ $10^{8}$ tonnes of both particulate (POC) and dissolved organic carbon (DOC) to the global ocean each year (Raymond \& Bauer 2001), representing more than the total amount of organic carbon buried in the world's oceans (Maranger et al. 2004). The most part of this carbon flux is primarily derived from terrestrial vegetation (Opsahl \& Benner 1997). Normally, this allochthonous carbon source is considered to be recalcitrant and transported conservatively to the ocean (Aminot et al. 1990, van Heemst et al. 2000). However, a labile and younger fraction of riverine DOC 
(e.g. recently decomposed litter fall and belowground sources), may also support the rapid remineralization of some fraction of terrestrially derived DOC (hereafter: terrestrial DOC) by bacterial communities along the river basin and once it enters the coastal ocean (Hedges et al. 1997).

Bacterial communities play a key role in biogeochemical cycles in the river-ocean continuum through different processes, including the degradation of autochthonous and allochthonous organic matter, the resulting $\mathrm{CO}_{2}$ production by heterotrophic respiration of terrestrial DOC, and/or the export of riverine waters with huge amounts of dissolved inorganic carbon (DIC) to the coastal ocean (Cole \& Caraco 2001, Raymond \& Bauer 2001). Bacterioplankton also represent a potential carbon source to higher trophic levels, as they can constitute a significant food item for different planktonic microbial grazers, crustaceans, and other freshwater and/or marine invertebrates (e.g. Nagata \& Okamoto 1988, Vargas \& González 2004).

Bacterial community structure also undergoes pronounced changes along the river-ocean environmental gradient (Fortunato \& Crump 2011), which is also reflected in their abundance and production (Vallières et al. 2008). Although variations in temperature, DOC availability and lability (Pace \& Cole 1996, Sinsabaugh et al. 1997), and inorganic nutrients (Castillo et al. 2003) appear to be major drivers for different bacterial assemblages, the river flow regime may also affect the productivity of certain bacterial communities during periods of high and/or low river flow (Edwards \& Meyer 1986). In adjacent river plume waters, bacterial production has been enhanced apparently as a result of bacterial utilization of terrestrial/riverine organic matter in addition to fresh DOC produced by phytoplankton, especially during the productive season of river-influenced upwelling areas (Sobarzo et al. 2007). In this sense, terrestrial DOC exported by rivers may also explain the occasional poor correlation between bacteria and phytoplankton on the continental shelves of eastern boundary regions (Ducklow \& Kirchman 1983).

Spatial and temporal patterns in the abundance and production of free-living heterotrophic bacteria have been investigated in lakes, estuaries, and in the ocean, as well as their regulatory processes (e.g. Cole et al. 1988, Findlay et al. 1991, Roland \& Cole 1999, Del Giorgio et al. 2006, Judd et al. 2006). However, the same cannot be said for studies that focus on both the estuarine system and its connections to more oceanic areas. The major objectives of the present study were: (1) to determine the temporal and spatial patterns in bacterial abundance (BA), biomass (BB), and production (BP) along one of the most important river basins in Chile, the Biobío River, and its adjacent upwelling coastal area, (2) to determine the relationship between BP and potential environmental control factors, such as temperature, nutrients, DOC, and other variables, along this river-ocean continuum under different scenarios of river flow regime and coastal upwelling processes in the adjacent ocean, and (3) by conducting isotopic measurements of $\delta^{13} \mathrm{C}$-DOC, to evaluate the influence of riverine DOC on bacterial productivity in this riverinfluenced coastal upwelling area. We hypothesized that highest BP and BB along the river-ocean continuum will be associated with areas with high anthropogenically or naturally derived nutrients and DOC. Furthermore, terrestrial DOC sources will significantly influence the biogeochemistry and BP of the adjacent river-influenced shelf during periods of high river flow in contrast to periods of coastal upwelling events. In the present study, bacterial assemblages were treated as a total community; we did not attempt to distinguish among species or functional groups.

\section{MATERIALS AND METHODS}

\section{Study area}

This study was carried out in the Biobío River basin and its adjacent coastal ocean, located off Central Chile (36 ${ }^{\circ}$; Fig. 1). The Biobío River is Chile's second longest river (after the Loa River), and the Biobío basin is Chile's third largest watershed (24 $\left.260 \mathrm{~km}^{2}\right)$. In its lower reaches, it passes through agricultural land, towns, cities, and industrial areas (Karrasch et al. 2006). The Biobío River is also among the most dramatically polluted freshwater bodies in Chile (Focardi et al. 1996), where $83 \%$ of the Chilean pulp production takes place. Mean daily flow rates range between 120 and $8500 \mathrm{~m}^{3} \mathrm{~s}^{-1}$, making this the most important hydrographic basin in terms of freshwater discharge in central-southern Chile. The hydrological regime is strongly influenced by a maximum flow rate peak during the rainy season in winter (JuneJuly) and a minimum flow rate during summer (February-March), with medium levels in spring due to ice melting (Barra et al. 2001). The runoff from this river supplies significant amounts of silicate, nitrate, phosphate, and trace metals to the coastal ocean (Sánchez et al. 2008). The adjacent coastal area is not only influenced by the seasonally variable flow of the Biobío River, but also by intense seasonal coastal upwelling events (Sobarzo et al. 2007). The seasonal 


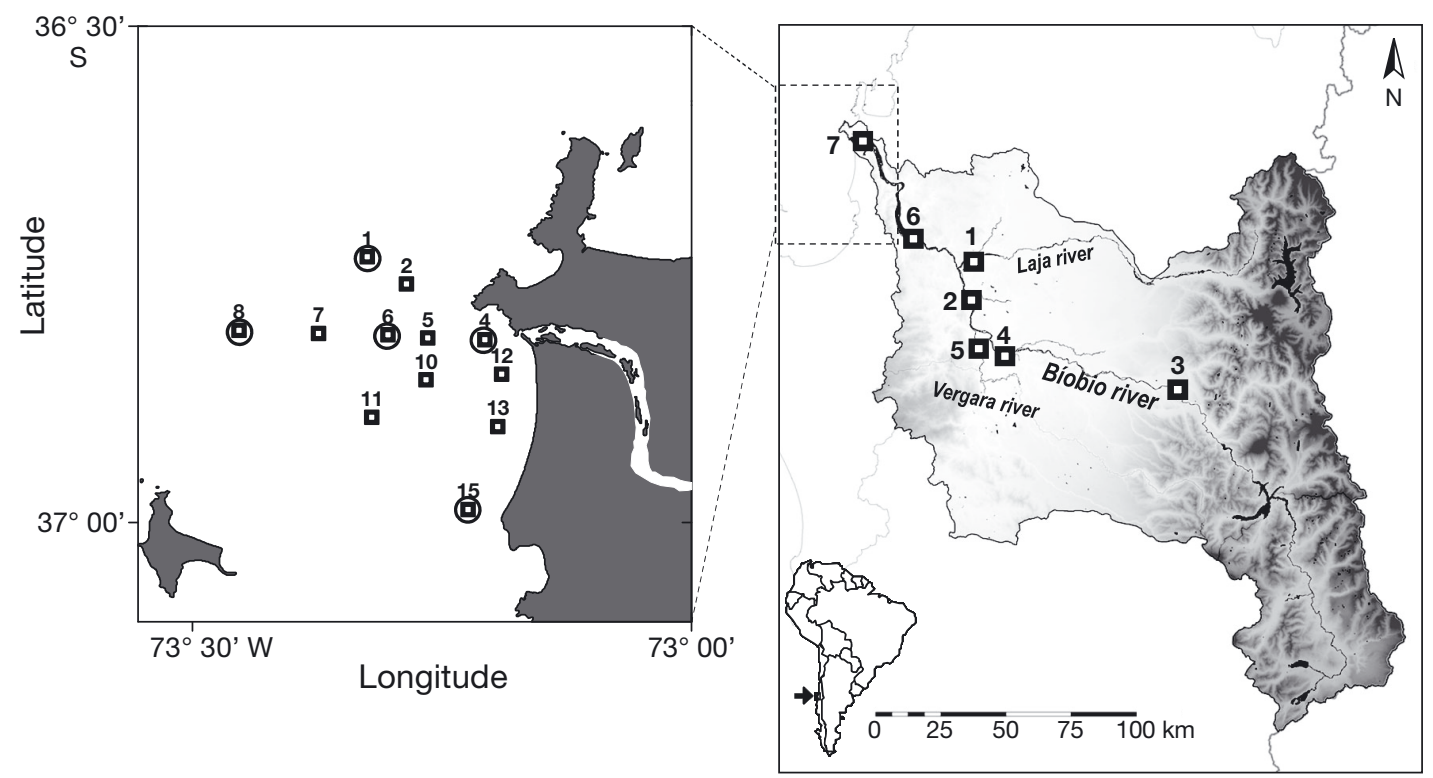

Fig. 1. Study area in Chile, including location of the sampling stations along the Biobío River basin and the adjacent coastal ocean. Chemical and bacterial production measurements were made at all river stations ( $\square$ ), whereas in the coastal ocean they were estimated only for some selected stations (-0). Hydrographic data were collected at all river-oceanic stations

variation of winds and runoff creates 2 distinct modes of water circulation in the adjacent continental shelf, viz. a highly productive summer upwelling season and a winter downwelling season with a thick surface layer to which maximum riverine freshwater flows are added (Sobarzo et al. 2007).

In the present study, we sampled 7 stations along the Biobío River, covering almost $200 \mathrm{~km}$, and including 2 stations located at the mouth of 2 important tributaries (Laja River, Stn 1; and Vergara River, Stn 5; Fig. 1). Physical, chemical, and biological measurements were taken at all river stations. Almost simultaneously, we conducted 3 research cruises along the adjacent continental shelves, including 12 sampling stations for hydrographic measurements and 5 to 6 stations for chemical analyses and BA, BB, and BP estimates (Table 1). Five sampling campaigns along the river basin were conducted between late July 2010 and January 2011, representing winter, spring, and summer conditions, and during each campaign, a 3 d cruise was conducted (Table 1).

\section{Water sampling and hydrography}

Dates for each sampling campaign are shown in Table 1, including all physical, chemical, and biological measurements taken at each site.

In the river, surface samples (10 l from the upper $1 \mathrm{~m}$ depth) were collected from the central channel of the river using a clean, sample-washed, plastic bucket. Considering the high energy levels of the river upstream and the reduced depth $(<2 \mathrm{~m})$ in the lower reaches, we did not collect depth-integrated water samples. Water samples were kept cold and dark until analysis, conducted on average within 2 to $7 \mathrm{~h}$ of sample collection. Temperature and conductivity were measured immediately before water sampling using WTW meters, whereas $\mathrm{pH}$ was measured spectrophotometrically. Subsamples were taken for analysis of BP (1 l ), BA and BB (50 ml fixed with $1 \%$ glutaraldehyde); nutrients $(500 \mathrm{ml})$, including nitrate $\left(\mathrm{NO}_{3}{ }^{-}\right)$, nitrite $\left(\mathrm{NO}_{2}^{-}\right)$, and orthophosphate $\left(\mathrm{PO}_{4}{ }^{3-}\right)$; and DOC $(30 \mathrm{ml})$. Additional samples were collected during winter and spring campaigns for measurement of DIC (30 ml) and POC (1-2 l), including their $\delta^{13} \mathrm{C}$ signatures.

During the oceanographic cruises in the adjacent ocean, temperature, salinity, and oxygen profiles were recorded from near the bottom to the surface using a SeaBird SBE-19 plus CTD equipped with a calibrated Beckman oxygen sensor (i.e. optical sensor that utilizes luminescent technology) and a Wetstar fluorometer. Water samples for chlorophyll a (chl $a, 1$ l), nutrients $(500 \mathrm{ml})$, and BA and BB (50 ml fixed with $1 \%$ glutaraldehyde) were collected at 2 , 10,20 , and $50 \mathrm{~m}$ depths with $10 \mathrm{l}$ Niskin bottles. Samples for BP (1 l), DIC (30 ml), DOC (30 ml), and POC (1-2 l), and their $\delta^{13} \mathrm{C}$ signatures were collected only at 2 and $10 \mathrm{~m}$ depth. 
Table 1. Summary of sampling information for spatiotemporal physical, chemical, and biological data. CDOM: colored dissolved organic matter. Carbon fractions - DIC: dissolved inorganic, DOC: dissolved organic, POC: particulate organic, TIC: total inorganic, TOC: total organic carbon

\begin{tabular}{|c|c|c|c|c|c|}
\hline $\begin{array}{l}\text { General information } \\
\text { Campaign }\end{array}$ & \multicolumn{3}{|c|}{ Environment } & Dates & Season \\
\hline RIVOM 4 & \multicolumn{3}{|c|}{ River/ocean } & 15 Jul-2 Aug 2010 & Winter \\
\hline RIVOM 5 & \multicolumn{3}{|c|}{ River } & 8 Sep 2010 & Winter \\
\hline RIVOM 6 & \multicolumn{3}{|c|}{ River/ocean } & 26 Oct-5 Nov 2010 & Spring \\
\hline RIVOM 7 & \multicolumn{3}{|c|}{ River } & 22 Dec 2010 & Spring \\
\hline RIVOM 8 & \multicolumn{3}{|c|}{ River/ocean } & 19-26 Jan 2011 & Summer \\
\hline \multicolumn{5}{|c|}{ Measurements per campaign } & \multirow[b]{2}{*}{ Method } \\
\hline Measurements & \multicolumn{2}{|c|}{$\begin{array}{ll}\text { Depth }(\mathrm{m}) & \text { River } \\
\text { Stn }\end{array}$} & \multicolumn{2}{|c|}{ Ocean } & \\
\hline Temperature & 1 & All & Profiles & All & $\begin{array}{c}\text { WTW meters or } \\
\text { SeaBird SBE-19 plus CTD }\end{array}$ \\
\hline Conductivity/salinity & 1 & All & Profiles & All & $\begin{array}{c}\text { WTW meters or } \\
\text { SeaBird SBE-19 plus CTD }\end{array}$ \\
\hline $\mathrm{pH}$ & & All & $2-20$ & $4,6,8$ & Spectrophotometry \\
\hline Chl a & 1 & All & Profiles & All & bbe FluoroProbe \\
\hline CDOM & 1 & All & Profiles & All & bbe FluoroProbe \\
\hline Nutrients & 1 & All & $2,10,20,50$ & $1,4,6,8,13,15$ & Standard methods \\
\hline DIC & 1 & All & 2,20 & $4,6,8$ & TIC-TOC analyzer \\
\hline DOC & 1 & All & 2,20 & $4,6,8$ & TIC-TOC analyzer \\
\hline POC & 1 & All & 2,20 & $4,6,8$ & TIC-TOC analyzer \\
\hline$\delta^{13} \mathrm{C}-\mathrm{DIC} \mathrm{C}^{\mathrm{a}}$ & 1 & All & 2,20 & $4,6,8$ & Isotope ration mass spectrometry \\
\hline$\delta^{13} \mathrm{C}$-DOC & 1 & All & 2,20 & $4,6,8$ & Isotope ration mass spectrometry \\
\hline$\delta^{13} \mathrm{C}-\mathrm{POC}^{\mathrm{a}}$ & 1 & All & 2,20 & $4,6,8$ & Isotope ration mass spectrometry \\
\hline Bacterial abundance & 1 & All & $2,10,15,20,50$ & $1,4,6,8,13$ & Epifluorescence \\
\hline Bacterial biomass (BB) & 1 & All & $2,10,15,20,50$ & $1,4,6,8,13$ & Epifluorescence \\
\hline Bacterial production (BP) & 1 & All & 2,20 & $1,4,6,8,13$ & L- $\left[{ }^{14} \mathrm{C}(\mathrm{U})\right]$-leucine \\
\hline Bacterial growth rate & 1 & All & 2,20 & $1,4,6,8,13$ & $\mathrm{BP}: \mathrm{BB}$ \\
\hline
\end{tabular}

Chl a measurements from the river and vertical profiles from the adjacent ocean were conducted with a FluoroProbe sensor (bbe-Moldaenke) (Beutler et al. 2002), which is a highly sensitive measuring instrument for the analysis of chlorophyll with algal class determination. By using the UV-LED signal recorded with the bbe FluoroProbe, we were able to record measurements of relative amounts of colored dissolved organic matter (CDOM), both along the river basin and throughout vertical profiles in the adjacent coastal ocean. Chlorophyll measurements with this equipment were calibrated by contrasting with analysis by fluorometry (Turner Design TD$700)$, using acetone (90\% v/v) for the pigment extraction of discrete samples according to standard procedures (Parsons et al. 1984).

All of these environmental variables were studied within the context of the seasonal variability in river flow, wind (derived Ekman transport), sea surface temperature (SST), and normalized water-leaving radiance at $555 \mathrm{~nm}$ (nLw555) fields. The signature of river plumes has been commonly detected and quantified using nLw555 in coastal waters (e.g. Nezlin \& DiGiacomo 2005).

L1A Moderate Resolution Imaging Spectroradiometer (MODIS) files were obtained from the NASA web site (http://oceancolor.gsfc.nasa.gov) and processed with high-resolution procedures for SST and nLw555. The processing procedure was carried out with high-resolution options and using SeaWIFS Data Analysis System (SeaDAS) software, in order to produce $1000 \mathrm{~m}$ resolution for SST and $500 \mathrm{~m}$ resolution for nLw555. A special atmospheric correction was applied to produce the nLw555 images according to Wang \& Shi (2007) to decrease potential error in ocean color products, considering that coastal waters can be highly affected by turbid conditions.

Daily river flow data were obtained from the Dirección General de Aguas, Chile (www.dga.cl), between winter 2010 and summer 2011. Moreover, wind data were obtained from a coastal meteorological station 

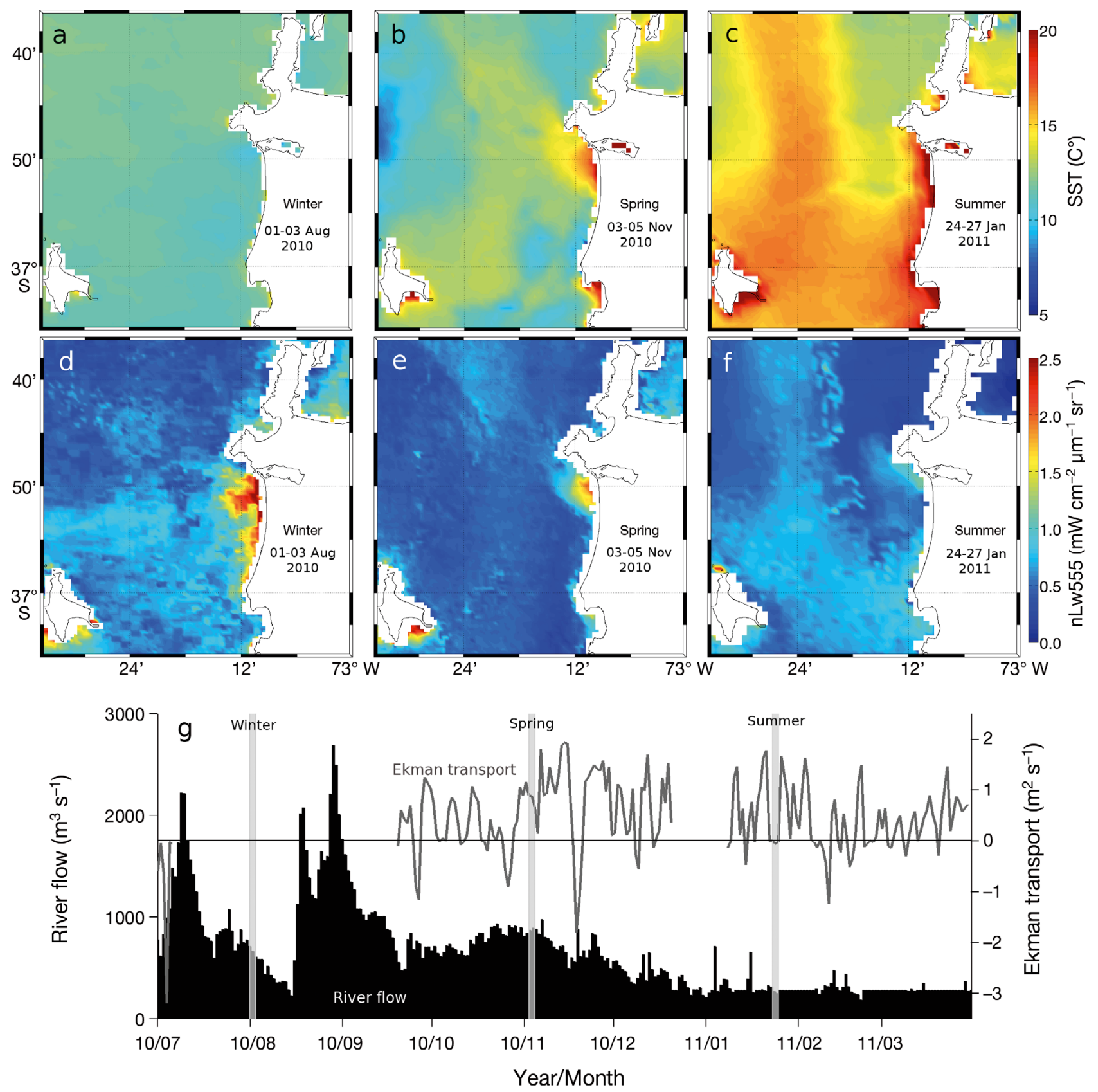

Fig. 2. (a-c) Composites of sea surface temperature (SST) and (d-f) normalized water-leaving radiance at $555 \mathrm{~nm}$ (nLw555), for the sampling periods during $(\mathrm{a}, \mathrm{d})$ winter, $(\mathrm{b}, \mathrm{e})$ spring, and $(\mathrm{c}, \mathrm{f})$ summer. $(\mathrm{g})$ River flow and Ekman transport for the study period during 2010 to 2011. Grey shaded areas represent the days on which the field sampling took place at the coastal ocean.

Positive (negative) values of Ekman transport represent offshore (onshore) transport of coastal water

$\left(36^{\circ} 42.28^{\prime} \mathrm{S}, 73^{\circ} 06.73^{\prime} \mathrm{W}\right)$, which is located next to the river mouth. Ekman transport was computed using the meridional component of wind stress, following Smith (1968). Seasonal variability of river flow and Ekman transport during the study period are presented in Fig. 2g.

\section{Chemical analyses}

Samples for nutrient analyses, including nitrate $\left(\mathrm{NO}_{3}{ }^{-}\right)$, nitrite $\left(\mathrm{NO}_{2}{ }^{-}\right)$, and orthophosphate $\left(\mathrm{PO}_{4}{ }^{3-}\right)$, were filtered through GF/F glass-fiber filters and frozen at $-20^{\circ} \mathrm{C}$ until analysis in the laboratory. 
Nitrate and orthophosphate concentrations were determined via spectrophotometry following Parsons et al. (1984) and Murphy \& Riley (1962). pH in seawater samples was also measured spectrophotometrically using the $m$-cresol purple method (Clayton \& Byrne 1993).

For DOC and $\delta^{13} \mathrm{C}$-DOC, a $30 \mathrm{ml}$ subsample was collected with a sterile syringe and filtered through a Swinex containing a GF/F filter of $0.7 \mu \mathrm{m}$, precombusted for 4 to $5 \mathrm{~h}$ at $450^{\circ} \mathrm{C}$. The samples were collected directly in $40 \mathrm{ml}$ glass 200 Series ICHEM $^{\circledR}$ vials, preventing the formation of any bubbles. For DIC and its $\delta^{13} \mathrm{C}$ signature, a $30 \mathrm{ml}$ subsample was collected with a sterile syringe and filtered through a Swinex containing a filter of $0.2 \mu \mathrm{m}$, and treated with $\mathrm{H}_{3} \mathrm{PO}_{4}$. The septa of vials were exchanged for butyl rubber septa to prevent diffusion of $\mathrm{CO}_{2}$. Samples were refrigerated at $5{ }^{\circ} \mathrm{C}$ until fast shipment for analysis. During the winter and spring campaigns, a final subsample (1.5 to 2 l) was filtered through combusted $\left(525^{\circ} \mathrm{C}\right.$ for $\left.4 \mathrm{~h}\right)$ glass fiber MFS GF/F filters $(0.7 \mu \mathrm{m}$ nominal pore size) to concentrate particles for POC concentration and its $\delta^{13} \mathrm{C}$ signature. In order to assess the stable carbon isotopic composition of potential anthropogenic sources, 2 additional POC samples were collected: 1 near $(<10 \mathrm{~m})$ a domestic wastewater treatment plant outfall, and the other from pulp mill effluent from a mill that produces newsprint from mechanically pulped softwood (pine). Filters were thawed, dried at $\sim 60^{\circ} \mathrm{C}$, acid-fumed overnight with $5 \% \mathrm{HCl}$, subsequently dried again at $60^{\circ} \mathrm{C}$, and held in a desiccator until analyzed. Freezedried degraded and fresh vegetation samples, representing the dominant natural carbon sources along the river (e.g. leaves of willows, birch, pine, grasses), as well as periphyton, were all ground in an agate mortar, dried at $\sim 60^{\circ} \mathrm{C}$, and packaged into tin cups.

Prior to analysis, DOC samples were bubbled with $\mathrm{CO}_{2}$-free nitrogen for $7 \mathrm{~min}$ to ensure complete removal of dissolved inorganic carbon. All samples were run on an OI Analytical TIC-TOC Analyzer Model 1030, first run to determine the ppm C organic/inorganic concentration, then for the $\delta^{13} \mathrm{C}$ isotope. The TIC-TOC analyzer was interfaced to a Finnegan Mat Delta Plus isotope ration mass spectrometer for analysis by continuous flow. Data were normalized using internal standards. The analytical precision was $2 \%$ for the quantitative measurements, and $\pm 0.2 \%$ for the isotopes. Analyses were conducted in the G.G. Hatch Isotope Laboratories at the University of Ottawa, Canada.

\section{Bacterioplankton abundance, biomass, and production}

The abundance and biomass of bacterioplankton (cells $\mathrm{l}^{-1}$ ) were determined by direct counting and epifluorescence microscopy (Porter \& Feig 1980). Freshwater/seawater ( 2 to $5 \mathrm{ml}$ ) containing bacteria were stained with 4',6-diamidino 2-phenylindole (DAPI) to a final concentration of $72 \mu \mathrm{M}$ and collected on black $25 \mathrm{~mm}$ polycarbonate filters $(0.2 \mu \mathrm{m}$ pore size). Bacterioplankton were counted with an epifluorescence microscope OLYMPUS ${ }^{\circledR}$ IX-51, equipped with UV model U-MWU2 (width band pass 330 to $385 \mathrm{~nm}$ ). Bacterial volume was calculated from length and width measurements of at least 50 cells sample $^{-1}$. The biovolumes were converted to carbon using the equation $\mathrm{C}(\mathrm{fg})=90.06 \times V\left(\mu^{3}\right) 0.59$, where $V$ is the bacterial volume (Simon \& Azam 1989).

The ambient BP was estimated from the L- $\left[{ }^{14} \mathrm{C}(\mathrm{U})\right]$-leucine incorporation rates (van Looij \& Riemann 1993). From each subsample, $10 \mathrm{ml}$ were transferred to sterile tubes (3 replicates and 1 blank). The blank was poisoned with $0.2 \mu \mathrm{m}$ filtered formaldehyde $(2 \%)$. For river samples, a saturation curve experiment was conducted at Stn 5 over 5 leucine concentrations ( 300 to $330 \mathrm{mCi}$ $\mathrm{mmol}^{-1}$ specific activity, Sigma T-6527), resulting in a saturation concentration of $75 \mathrm{nM}$. For marine samples, we added leucine to obtain final saturation concentrations of $50 \mathrm{nM}$, which was reported as the mean saturation level for this coastal area by Hernández et al. (2006). All tubes were incubated in the dark for $1 \mathrm{~h}$ at the simulated in situ water temperature $\left( \pm 2^{\circ} \mathrm{C}\right)$. We also selected the incubation period for both sampling stations considering previous studies in the same coastal region (Troncoso et al. 2003, Hernández et al. 2006). After incubation, ${ }^{14} \mathrm{C}$-leucine incorporation was stopped by adding $2 \%$ formaldehyde. The samples were precipitated with ice-cold trichloroacetic acid (TCA, final concentration of $5 \%$ ) for $10 \mathrm{~min}$. Samples were kept cool, filtered onto $0.45 \mu \mathrm{m}$ cellulose nitrate filters (Whatman), and rinsed 3 times with $5 \mathrm{ml}$ of $5 \%$ ice-cold TCA. In the filtrate, the occurrence of large sediment particles or clumps was relatively low and represented less than 5 to $10 \%$ of the total number of filters analyzed during our study. Nevertheless, BP estimates represented both free-living cells and some bacteria attached to small particles. The filters were placed into scintillation vials and dissolved in $1 \mathrm{ml}$ of ethyl acetate. A volume of $10 \mathrm{ml}$ of liquid scintillation cocktail (Eco- 
lite $\left.{ }^{\circledR}\right)$ was added and the samples were radio assayed. Leucine uptake was estimated from dpm using a Packard (Model 1600TR) liquid scintillation counter; counting efficiency was calculated from the non-quenched standard of ${ }^{3} \mathrm{H}$-toluene. BP from leucine incorporation was calculated using a ratio of cellular carbon to protein of 0.86 and a fraction of leucine in protein of 0.073 (Simon \& Azam 1989). The cell production rates, obtained from moles of leucine incorporated (see Fuhrman \& Azam 1982), were transformed to BP assuming a widely used conversion factor of $2 \times 10^{18}$ cells per mole of leucine incorporated (Lee \& Fuhrman 1987). Bacterial (specific) growth rates (BGR) were calculated as $\mathrm{BP} \times \mathrm{BB}^{-1}$.

Given that several of our environmental measurements were non-independent (e.g. pH and conductivity/salinity), a principal component analysis (PCA) was used to separate environmental variability into orthogonal vectors, which were computed as linear combinations of the environmental variables originally measured. Previously, data requirements for the PCA analysis were checked according to Reimann et al. (2008). We used the principal components that explained the largest percentage of total variance $(>15 \%)$ to represent environmental variability along the river and the adjacent coastal ocean. A Spearman correlation analysis (SPC) was then conducted to explore the connection between these principal components and BA, BB, and BP.

\section{RESULTS}

\section{Meteorological, hydrological, and oceanographic conditions}

The observed wind conditions showed the typical seasonal change between winter and summer months, with northerly winds (coastal subsidence) during the winter, and southerly winds (upwelling) during spring and summer (Fig. 2g). It also was possible to observe synoptic wind fluctuations within the range of 2 to $15 \mathrm{~d}$, which can mask the seasonal signal, meaning that none of the 3 cruises in the riverinfluenced area were carried out under intense coastal upwelling conditions. The winter sampling was carried out with northerly winds (subsidence). In contrast, the spring cruise was conducted during weak southerly winds favorable to upwelling, and the summer cruise was conducted during coastal upwelling relaxation (Fig. 2g). This led to homogeneous and cold surface waters during winter (around $12^{\circ} \mathrm{C}$ ) and warmer waters during spring, and especially in summer (Fig. 2a-c). The Biobío River showed maximum flows in winter and spring, and a decline from December onwards (Fig. 2g), which was reflected by a greater region of freshwater influence in winter than spring and summer (Fig. 2d-f). The high river flow in winter and northerly winds pushed the 34 isohaline below $40 \mathrm{~m}$ during the winter sampling period (Fig. 3a). With the arrival of upwelling-favorable
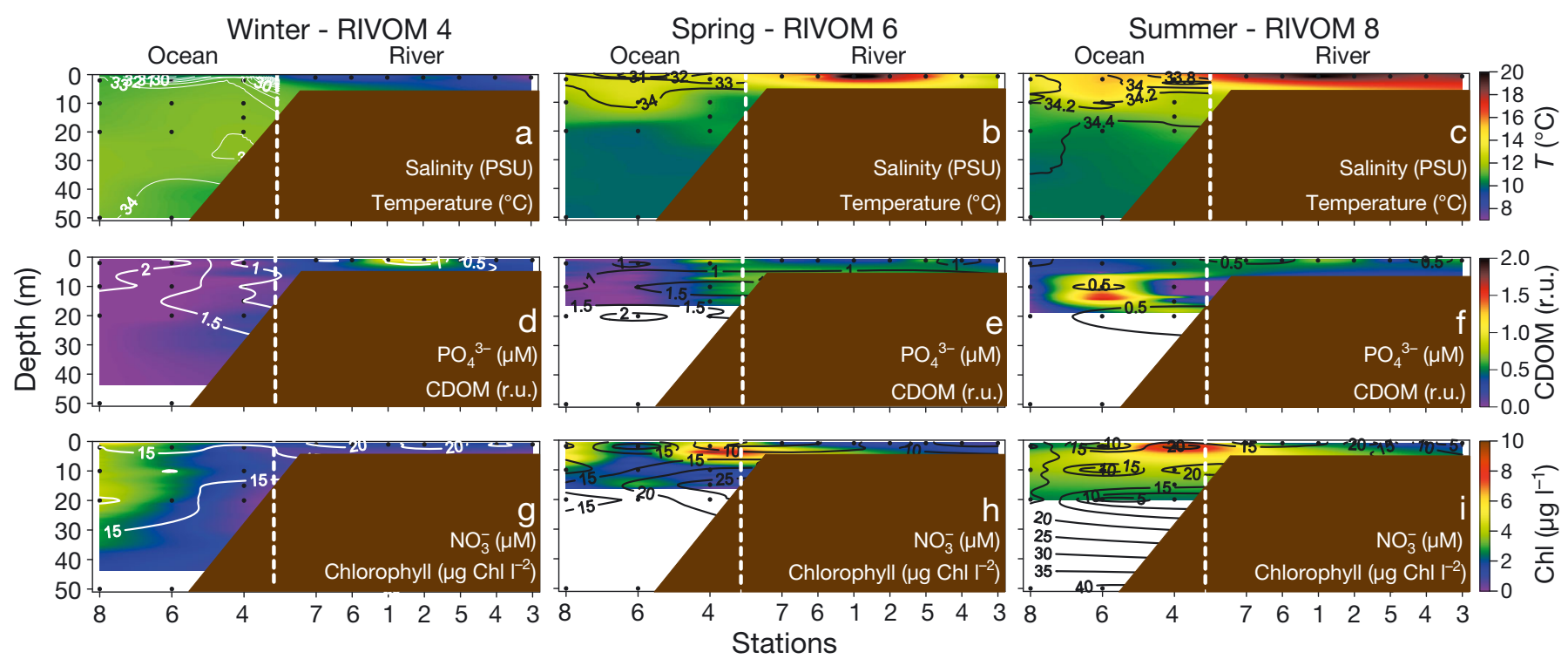

Fig. 3. (a-c) Temperature, (d-f) colored dissolved organic matter (CDOM), and ( $\mathrm{g}-\mathrm{i})$ total chlorophyll along 10 sampling stations from the Biobío River to the adjacent coastal ocean averaged for the 3 major field campaigns under $(a, d, g)$ winter, $(b, e, h)$ spring, and $(\mathrm{c}, \mathrm{f}, \mathrm{i})$ summer conditions. Isopleths of $(\mathrm{a}-\mathrm{c})$ salinity, $(\mathrm{d}-\mathrm{f})$ phosphate, and $(\mathrm{g}-\mathrm{i})$ nitrate concentration are also included. Brown area: mean river depth and slope towards adjacent ocean. RIVOM: sampling campaigns, see Table 1 
winds in spring and summer and the decline of river flow, the 34 isohaline was located at $10 \mathrm{~m}$ in spring; during summer the 34.4 isohaline reached $20 \mathrm{~m}$ depth (Fig. 3b,c). River temperature, meanwhile, was cooler in winter and warmer in summer relative to oceanic waters. This combination of wind and flow conditions caused haline stratification in winter, thermal stratification in spring and summer, and winter thermal inversion near the river mouth.

\section{Spatial-temporal environmental variability along the river-ocean continuum}

Low $\mathrm{PO}_{4}{ }^{3-}$ concentrations $(<1.5 \mu \mathrm{M})$ were observed along the river in comparison to the adjacent coastal ocean (Fig. 3d-f; 2-way analysis of variance, ANOVA, $F=4.1, \mathrm{p}=0.02 ; F=13.1, \mathrm{p}=0.005)$. Highest $\mathrm{PO}_{4}{ }^{3-}$ values were always observed at Stn 2 at the mouth of the Laja River, one of the main tributaries of the Biobío River. $\mathrm{NO}_{3}{ }^{-}$concentrations in the river were higher during winter, especially in the lower reaches (Stns 6 and 7) and the more industrialized area ( $20 \mu \mathrm{M}$, Stns 2 and 5; Fig. 3g). In the adjacent coastal area, the $\mathrm{NO}_{3}{ }^{-}$concentration increased from winter to summer, when a high concentration (>30 $\mu \mathrm{M})$ was observed in sub-surface waters (down to $30 \mathrm{~m}$ depth), probably associated with upwelling events (Fig. 3i). Chl a was relatively low along the river $\left(<3 \mu \mathrm{g} \mathrm{l}^{-1}\right.$; Fig. $3 g-i)$. Low chl a values were observed during winter in the nearshore area, with a conspicuous increase offshore (4-5 $\mu g \mathrm{l}^{-1}$; Fig. $3 g$ ). Highest chl a concentrations were observed during the spring and summer campaigns (1-way ANOVA, $F=14.4$, p < 0.001), mainly associated with the upper $10 \mathrm{~m}$ of the river plume area (Stn 4 ; Fig. 3h,i). pH measurements (data not shown) did not show significant differences along the river, with the exception of Stn 5 (Vergara River mouth, $\mathrm{pH}=5.8$ to 6.8 ); in the coastal ocean, low $\mathrm{pH}$ values ( 7 to 7.5 ) were only associated with river plume waters. Although we estimated the relative concentration of CDOM by only using the FluoroProbe, it was evident that highest values during spring and summer were associated with the river mouth and river plume areas, with a sub-surface maximum at $15 \mathrm{~m}$ depth during summer (Fig. 3e,f).

DOC was highly variable along the river, with large intra-seasonal differences between field campaigns, especially during winter (1-way ANOVA, F= 9.3, $\mathrm{p}=0.009$; Fig. 4a). In the river, DOC ranged from 50 up to $800 \mu \mathrm{M}$. Highest concentrations were observed in winter, especially in September at the Vergara river mouth (Stn 5) and Biobío river mouth
(Stn 7; Fig. 4a). In spring, DOC concentrations decreased to an average of 100 to $200 \mu \mathrm{M}$, with a peak in the upper river section in December (Fig. 4b). In the coastal zone, DOC concentrations ranged from 200 to $400 \mu \mathrm{M}$, and large variability resulted in nonsignificant differences between the river and the coastal zone (1-way ANOVA, $F=0.16, p=0.69$ ). A slightly higher concentration was observed in the surface layer at $2 \mathrm{~m}$ depth, but differences were not significant (1-way ANOVA, $F=0.08, \mathrm{p}=0.924$ ). Nevertheless, significant differences in DOC concentration among seasons were observed (1-way ANOVA, $F=5.69, \mathrm{p}=0.006)$. Highest DOC values were observed in summer, mostly offshore; these values were significantly higher than results from the winterspring campaign (Tukey test, $\mathrm{p}=0.003$ ). This also fit with higher relative concentrations of CDOM observed during the summer campaign (Fig. 3f).

Several aspects of the $\delta^{13} \mathrm{C}$ values of DOC along the river-ocean continuum are worth noting. Large intraseasonal heterogeneity in $\delta^{13} \mathrm{C}$-DOC was observed between winter sampling campaigns (Fig. 4a). The $\delta^{13} \mathrm{C}$-DOC values in the river were clearly more depleted during September (-28 to $-33 \%$ ) than in July ( -25 to $-27 \%$ ), especially in the upper river and the river mouth area (1-way ANOVA, $F=12.01, \mathrm{p}=$ 0.004 ; Fig. 4a). In contrast, $\delta^{13} \mathrm{C}$-DOC values between October and December did not show evidence of qualitative changes among campaigns (KruskalWallis test, $H_{0.4,2.1}=0.42, \mathrm{p}=0.54$; Fig. $4 \mathrm{~b}$ ).

Degraded and fresh vegetation showed $\delta^{13} \mathrm{C}$ values between -31 and $-27 \%$. Both degraded and fresh vegetation $\delta^{13} \mathrm{C}$ values were within the range of $\mathrm{C} 3$ land plants (Meyers 1997), although C4 grasses $(-17.5 \%)$ were dominant along this river section at Stn 6. More depleted values $(\leq-30 \%$ ) were associated with willows and cottonwood trees at Stns 2 and 1 , and weeds collected at Stn 4 (Table 2). The $\delta^{13} \mathrm{C}$ composition of anthropogenic sources, such as domestic sewage and paper mill effluent, showed values of $\delta^{13} \mathrm{C}$ of -27.4 and $-27.6 \%$, respectively.

In general terms, in the adjacent coastal ocean there was a slight difference in the $\delta^{13} \mathrm{C}$ signal between the surface $(2 \mathrm{~m})$ and subsurface $(10 \mathrm{~m})$ layers. More depleted $\delta^{13} \mathrm{C}$ values were observed in subsurface waters, suggesting that sources other than riverine allochthonous DOC might have influenced $\delta^{13} \mathrm{C}$ values in surface layers. During winter and spring, $\delta^{13} \mathrm{C}$-DOC in the adjacent ocean ranged from -24 to $-28 \%$, and the data did not show contrasting alongshelf changes (Fig. 4a,b). During spring, $\delta^{13} \mathrm{C}-\mathrm{DOC}$ exhibited a range of only $2 \%$, from -26 to $-28 \%$, between marine and freshwater DOC, respectively. 


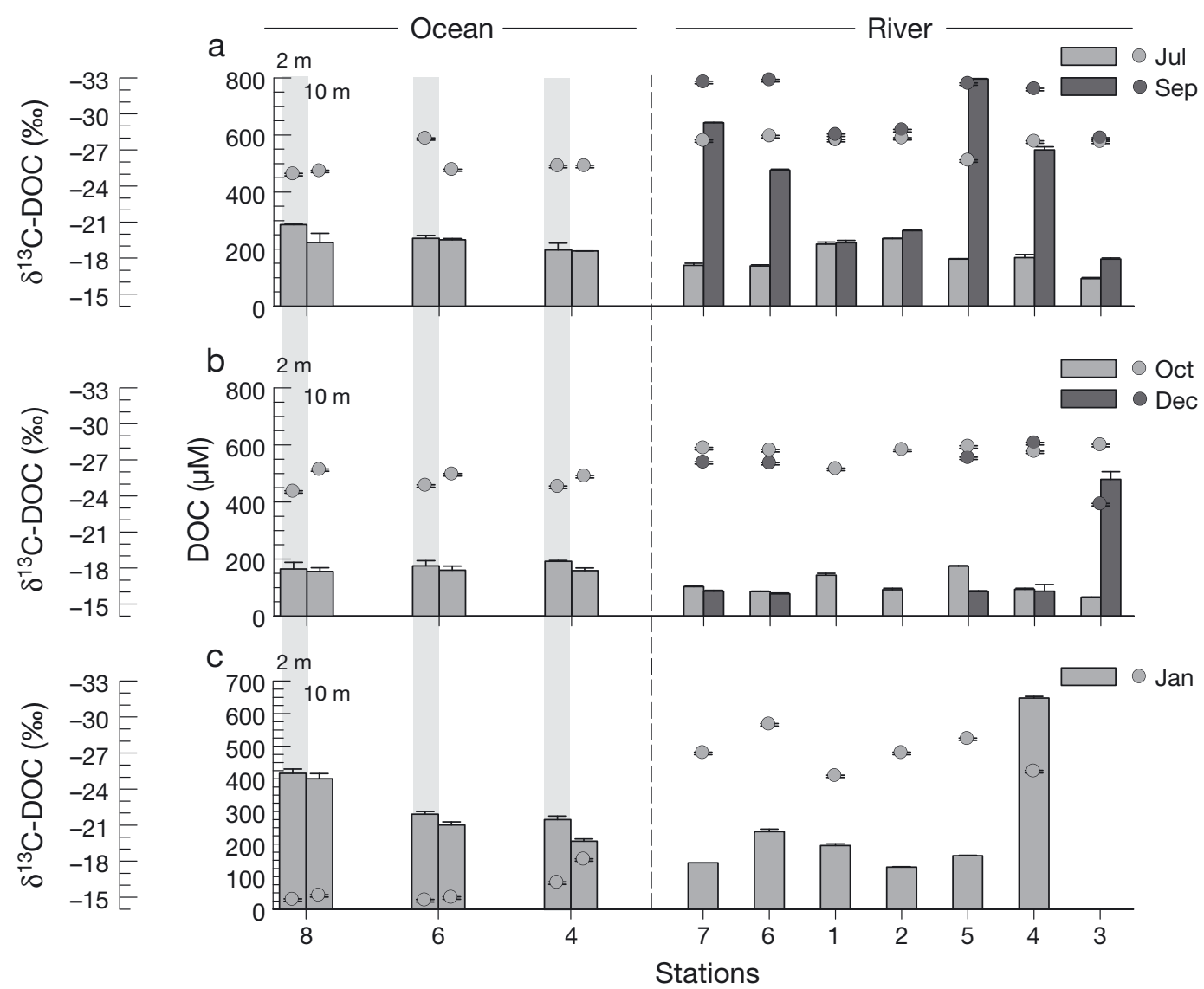

Fig. 4. Mean $( \pm \mathrm{SD})$ concentration of dissolved organic carbon (DOC) (bars) and $\delta^{13} \mathrm{C}$-DOC (dots) along the Biobío River and the adjacent coastal ocean (sampling depth: $2 \mathrm{~m}$ [shaded] and $10 \mathrm{~m}$ ) across a 10-station transect, during (a) July and September (winter), (b) October and December (spring), and (c) January (summer) months. Note: small error bars may not be visible

Table 2. Carbon stable isotopic composition $\left(\delta^{13} \mathrm{C}_{i} \%\right.$ of of the dominant vegetation across the Biobío River. Standard deviations of $\delta^{13} \mathrm{C}$ measurements averaged $\sim 0.1 \%$. For comparison, 2 anthropogenic organic matter sources had $\delta^{13} \mathrm{C}$ measurements of -27.4 (domestic sewage) and-27.6 (paper mill effluent). Stations are in the order from upstream to downstream (see Fig. 1)

\begin{tabular}{|lccccccc|}
\hline Stn & Grasses & Cottonwood & Weeping willow & Eucalyptus & Birch & Pine & Aromo \\
\hline 3 & -28 & -28.6 & & & & \\
4 & -30.5 & & & & & -22.6 \\
5 & & & & & -27.1 & & -17.9 \\
2 & -29.8 & -31.9 & -30.24 & & & -28.9 \\
1 & -28.4 & -30.7 & -30.99 & -28.8 & -29.5 & -27.6 & -13.9 \\
6 & -17.5 & & -29.4 & & & \\
\hline
\end{tabular}

Under upwelling conditions in summer, $\delta^{13} \mathrm{C}$-DOC was evidently enriched. $\delta^{13} \mathrm{C}$-DOC ranged from -18 to $-15 \%$ from the river plume to offshore waters (Fig. 4c).

The $\delta^{13} \mathrm{C}$-DOC pattern was different from the $\delta^{13} \mathrm{C}$ POC pattern, since $\delta^{13} \mathrm{C}$-DOC values were depleted not only along the river ( -33 to $-26 \%$ ), but also in the adjacent coastal ocean ( -28 to $-25 \%$ ), as far as 20 nautical miles. from the coast (Stn 8; Fig. 4). In contrast, $\delta^{13} \mathrm{C}$-POC showed a clear enrichment pattern, from depleted values in the river $(-28$ to $-25 \%$ ) to more enriched values in the coastal ocean $(-23$ to $-18 \%$ ), which suggests that autochthonous carbon production probably heavily influences the isotopic POC signature in the water column, especially under spring-summer conditions, and river discharge imposes a more significant effect on the DOC pool supporting BP in coastal waters (Fig. 5).

A PCA of environmental data available during all field campaigns (i.e. DIC and POC were not included because of the incomplete data set) produced a first principal component (PC1) that explained $26 \%$ of 


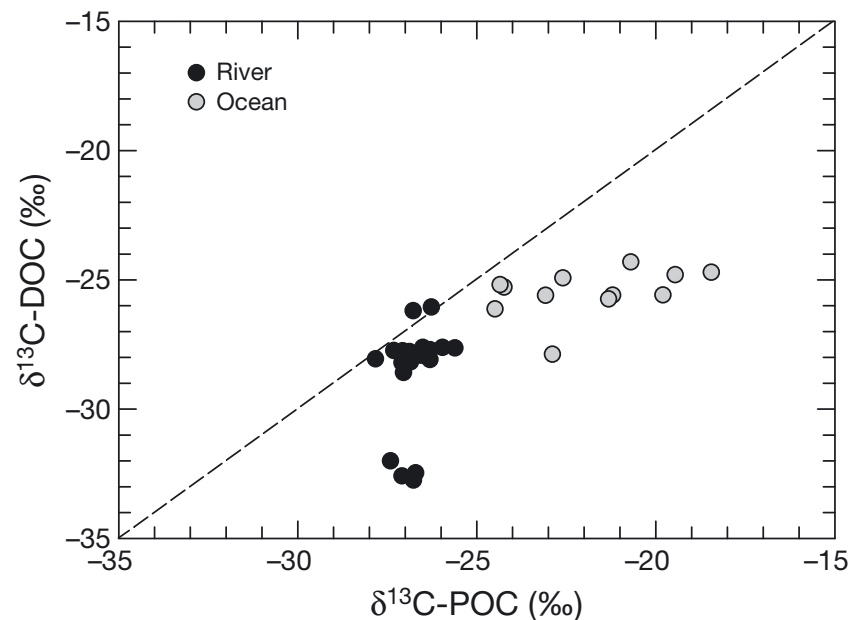

Fig. 5. Relationship between $\delta^{13} \mathrm{C}$-POC and $\delta^{13} \mathrm{C}$-DOC for both river and ocean sampling stations

Table 3. (a) Principal component analysis (PCA) performed on environmental data collected across the river and the coastal ocean. Columns show the weights assigned to originally measured variables. Only the components that explained more than $15 \%$ of the total variance are reported. Assigned weights $\geq 0.4$ are marked in bold. (b) Spearman correlation analysis (SPC) between the reported principal component and bacterial abundance (BA), biomass (BB), production (BP), and growth rate (BGR). Raw data were logtransformed before analyses. Significant correlations at ${ }^{*} \mathrm{p}<$ 0.05 and ${ }^{* *} \mathrm{p}<0.01$ are marked in bold. CDOM: colored dissolved organic matter, DOC: dissolved organic carbon

\begin{tabular}{|c|c|c|c|c|}
\hline \multirow{3}{*}{$\begin{array}{l}\text { (a) Physical/chemical } \\
\text { variable }\end{array}$} & \multicolumn{4}{|c|}{ _Principal component } \\
\hline & \multicolumn{2}{|c|}{ River } & \multicolumn{2}{|c|}{ Coastal ocean } \\
\hline & PC1 & PC2 & PC1 & $\mathrm{PC} 2$ \\
\hline $\mathrm{pH}$ & 0.36 & -0.04 & -0.17 & -0.44 \\
\hline Temperature $\left({ }^{\circ} \mathrm{C}\right)$ & 0.41 & -0.30 & 0.33 & -0.04 \\
\hline $\begin{array}{l}\text { Conductivity }(\mu \mathrm{S}) / \\
\text { salinity (PSU) }\end{array}$ & 0.45 & -0.28 & 0.38 & -0.03 \\
\hline $\mathrm{NO}_{3}^{-}(\mu \mathrm{M})$ & 0.15 & 0.43 & -0.07 & 0.55 \\
\hline $\mathrm{NO}_{2}^{-}(\mu \mathrm{M})$ & 0.33 & -0.08 & -0.35 & 0.34 \\
\hline $\mathrm{PO}_{4}{ }^{3-}(\mu \mathrm{M})$ & -0.01 & -0.34 & -0.43 & 0.04 \\
\hline $\mathrm{N}: \mathrm{P}$ ratio & 0.11 & 0.62 & 0.18 & 0.40 \\
\hline Chlorophyll ( $\mu \mathrm{g}$ chl a $\left.\mathrm{l}^{-1}\right)$ & 0.18 & 0.09 & 0.11 & 0.32 \\
\hline CDOM (relative unit) & 0.26 & -0.08 & 0.24 & 0.27 \\
\hline DOC $(\mu \mathrm{M})$ & -0.32 & -0.32 & 0.29 & -0.21 \\
\hline$\delta^{13} \mathrm{C}-\mathrm{DOC}(\%)$ & 0.40 & 0.16 & 0.48 & 0.01 \\
\hline$\%$ Total variance & 26 & 19 & 36 & 23 \\
\hline \multirow[t]{2}{*}{ (b) Principal component } & \multicolumn{4}{|c|}{ - Measurements - } \\
\hline & BA & BB & BP & BGR \\
\hline \multicolumn{5}{|l|}{ River } \\
\hline PC 1 & $0.55^{* *}$ & $0.62^{* *}$ & $0.50^{*}$ & * 0.19 \\
\hline PC 2 & 0.12 & 0.27 & -0.11 & $-0.35^{*}$ \\
\hline \multicolumn{5}{|l|}{ Coastal ocean } \\
\hline PC 1 & $0.67^{* *}$ & 0.31 & -0.08 & 0.13 \\
\hline PC 2 & -0.18 & -0.34 & -0.13 & 0.13 \\
\hline
\end{tabular}

total variability of the river data (Table 3a). An inspection of the highest weights $(>0.4)$ assigned by PC1 to the original variables showed that variability in temperature and conductivity had the largest weights, followed by $\delta^{13} \mathrm{C}$-DOC. The second principal component (PC2) explained an additional 19\% of total variability (Table 3a). The signs of the largest weights assigned by $\mathrm{PC} 2$ to the original variables were associated with variability in nutrients $\left(\mathrm{NO}_{3}{ }^{-}\right.$and $\mathrm{N}: \mathrm{P}$ ratio). Similarly, in the coastal area, a first principal component (PC1) explained $36 \%$ of total variability and assigned the largest weight to $\mathrm{PO}_{4}{ }^{3-}$ concentrations and $\delta^{13} \mathrm{C}$ DOC (Table 3a), whereas a second principal component (PC2) explained $23 \%$ of total variability, with the largest weight associated with $\mathrm{pH}$ and nutrient variability $\left(\mathrm{NO}_{3}{ }^{-}\right.$and $\mathrm{N}$ :P ratio; Table $\left.3 \mathrm{a}\right)$.

\section{Abundance, biomass, and bacterial production along the river-ocean continuum}

$\mathrm{BA}$ and $\mathrm{BB}$ were significantly higher in the coastal ocean compared to riverine waters (ANOVA, $F=$ $22.3, \mathrm{p}<0.01$ and $F=36.7, \mathrm{p}<0.01$, respectively; Fig. 6). In general terms, small cells $\left(<0.3 \mu^{3}\right)$ numerically dominated the bacterial communities along the river (data not shown). In consequence, by using $0.45 \mu \mathrm{m}$ cellulose nitrate filters for $\mathrm{BP}$, those estimates could have been underestimated in these samples. In contrast, coastal bacterioplankton communities ranged from 0.7 to $0.9 \mu^{3}$, with maximum volumes offshore, which indeed resulted in higher coastal biomasses. Along the river, BA and BB were always higher in the lower reaches at Stns 6 and 7 (15 to 80 cells ml ${ }^{-1} \times 10^{5} ; 30$ to $70 \mu \mathrm{g} \mathrm{Cl}^{-1}$ ). Non-significant differences were observed in $\mathrm{BA}$ and $\mathrm{BB}$ among seasons $(\mathrm{ANOVA}, F=4.07, \mathrm{p}=0.02$ and $F=6.3, \mathrm{p}=$ 0.004 , respectively).

In the adjacent coastal area, BA was seasonally different (ANOVA, $F=6.2, \mathrm{p}=0.003$ ), and clearly increased from winter to summer campaigns, on average from $10^{5}$ to $10^{7}$ cells ml ${ }^{-1}$ (Fig. 6). However, biomasses displayed non-significant differences among sampling seasons (ANOVA, $F=2.8, \mathrm{p}=0.06$ ), probably associated with differences in cell volume. An extreme maximum of BA $\left(1.8 \times 10^{7}\right.$ cells ml $\left.^{-1}\right)$ and biomass $\left(\sim 220 \mu \mathrm{g} \mathrm{Cl}^{-1}\right)$ was observed associated with river plume waters during summer. In fact, both during spring and summer, high biomasses were observed in river plume waters (Stns 4 and 6), where maximum chl $a$ and CDOM were also observed (Figs. 3h,i, \& 7d,f). Integrated biomasses were not significantly different among sampling campaigns 


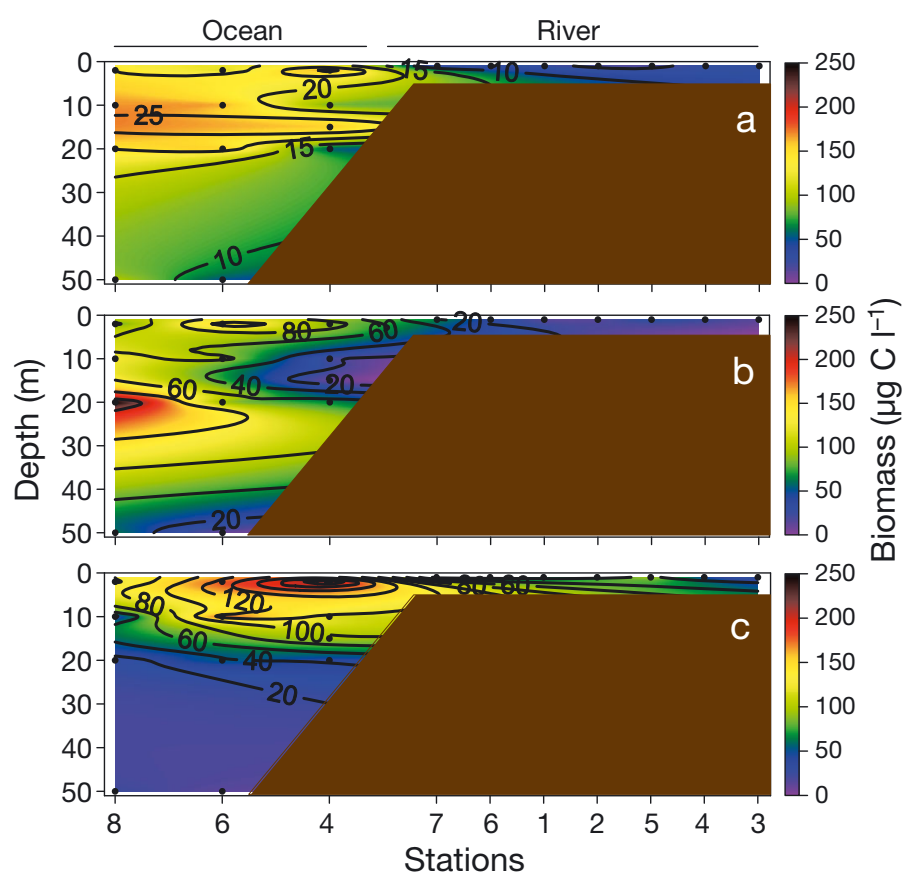

Fig. 6. Isopleths of bacterial abundance (isolines; $10^{5}$ cells $\mathrm{ml}^{-1}$ ) and biomass (color shading) along 10 sampling stations from the Biobío River to the adjacent coastal ocean averaged for the 3 major field campaigns under (a) winter, (b) spring, and (c) summer conditions. Brown area: see Fig. 3

( $t$-test, $t=1.2, \mathrm{df}=11, \mathrm{p}=0.24)$. However, during winter and spring, integrated biomasses increased offshore (Fig. 7a,c). In contrast, during summer, high values were observed off the river mouth area, and southward associated with less saline waters with high relative CDOM concentration (Fig. 7e). SPC between each principal component explaining environmental variability (Table $3 \mathrm{~b}$ ), showed that along the river, $\mathrm{BA}$ and $\mathrm{BB}$ were positively $\left(\mathrm{r}_{\mathrm{s}}=0.55\right.$ and 0.62 , respectively) and significantly correlated with PC1 (temperature/conductivity and $\left.\delta^{13} \mathrm{C}-\mathrm{DOC}\right)$, whereas in the coastal ocean, only BA was positively $\left(\mathrm{r}_{\mathrm{s}}=0.67\right)$ and significantly correlated with PC1 $(\mathrm{pH}$ and nutrient variability; Table $3 \mathrm{~b}$ ).

$\mathrm{BP}$ in the river ranged from 3.1 to $92.8 \mu \mathrm{g} \mathrm{C}^{-1} \mathrm{~d}^{-1}$ (Fig. 8). BGR also showed a wide range of values, from 0.002 to $10.1 \mathrm{~d}^{-1}$. Significant differences in BP were found among sampling campaigns (ANOVA, $F=22.3, \mathrm{p}<0.01$ ), with the highest rates during spring and summer periods (Fig. 8b,c). In contrast, highest BGR values were observed during winter and spring, but with significant differences in both BP and BGR within the same sampling season (t-test, $\mathrm{p}<0.01$ ), which reflects the high variability of this riverine system. On average, BP and BGR were always higher in the more anthropogenically influenced areas at Stn 5 (Vergara River, near a domestic sewage plant) and Stn 2 (i.e. near a pulp mill indus- try), as well as at Stns 6 and 7, close to more urbanized areas (i.e. the village of Santa Juana and the city of Concepcion, respectively). In contrast, BP and BGR were commonly low $\left(<25 \mu \mathrm{g} \mathrm{C} \mathrm{l^{-1 }} \mathrm{d}^{-1}\right.$ and $<1 \mathrm{~d}^{-1}$, respectively) in the upper and less anthropogenically influenced river sector (Stn 3; Fig. 8). A correlation analyses between river flow and BP in the upper and lower river sections showed that highest BP was observed during periods of low river flow, but only in the lower reaches of Biobío River $\left(\mathrm{r}^{2}=0.46, \mathrm{p}\right.$ $=0.04$; Fig. 9a). BP along the river was positively $\left(\mathrm{r}_{\mathrm{S}}=\right.$ 0.5) and significantly correlated with PC1 (temperature/conductivity and $\delta^{13} \mathrm{C}$-DOC), whereas BGR was negatively $\left(\mathrm{r}_{\mathrm{s}}=-0.35\right)$ and significantly correlated with PC2 (variability in nutrients), which in turn would suggest that highest BGR was associated with low $\mathrm{N}: \mathrm{P}$ and $\mathrm{NO}_{3}{ }^{-}$waters (Table $3 \mathrm{~b}$ ).

BP was significantly lower in the adjacent coastal ocean (ANOVA, $F=12.7, p=0.0008$ ), where it showed highest rates in the surface layer of the river plume (ANOVA, $F=5.69, \mathrm{p}=0.006$ ), with the highest $\mathrm{BP}$ and BGR observed during the spring campaign (Fig. 8b). During both winter and spring, surface BP decreased longitudinally from inland towards offshore waters (Fig. 8a,b). Integrated BP in the upper $20 \mathrm{~m}$ ranged from 14.3 to $1035 \mathrm{mg} \mathrm{C} \mathrm{m}^{-2} \mathrm{~d}^{-1}$ (Fig. 7). Significant differences were observed in integrated BP among sampling seasons ( $t$-test, $t=-2.5$, df $=9$, $\mathrm{p}=0.03$ ), with the highest integrated BP occurring during the spring cruise, near the Biobío River mouth (Stn 4, Fig. 7d), where relative CDOM concentration also peaked (Fig. 7d). At that time, BP was also high south of the river mouth (Fig. 7d), predominantly in the river plume direction (Fig. 2). Neither BP nor BGR were correlated significantly with PCs describing coastal environmental variability (Table $3 b$ ). Finally, when we analyzed the relationship between $\delta^{13} \mathrm{C}$ DIC along the river-ocean continuum and BP, a significant negative correlation was found for riverine bacterial communities $\left(\mathrm{r}^{2}=0.47, \mathrm{p}=0.00007\right)$, which suggests that BP peaked when isotopically depleted DIC (possibly as a result of terrestrial organic matter respiration) dominated in river waters (Fig. 9b).

\section{DISCUSSION}

Many rivers in Chile discharge their waters to the coastal ocean, and most of them are relatively short, which implies strong environmental gradients over relatively short distances. In this study, we considered this environmental gradient when looking at one of the most important river basins in Chile, 

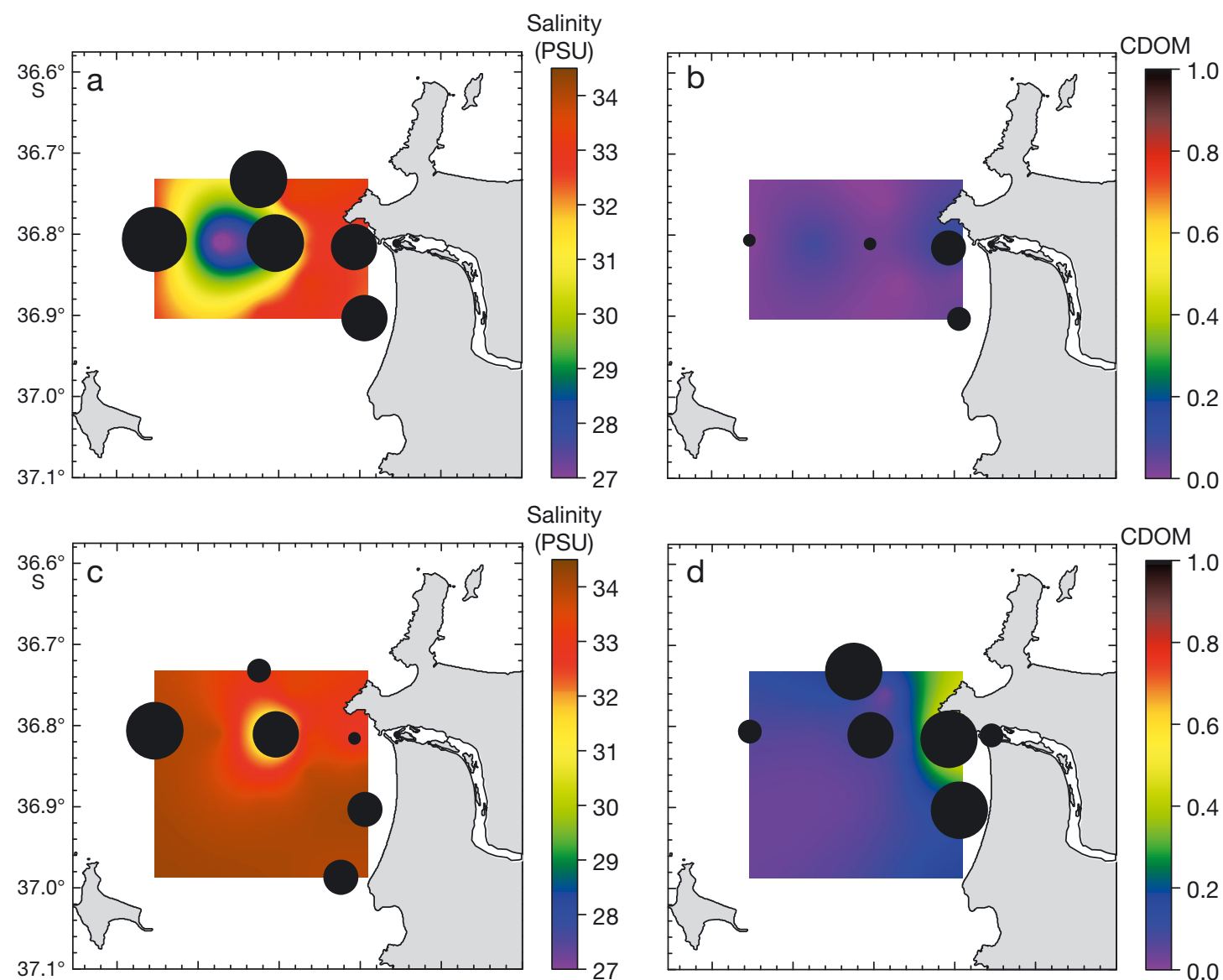

Salinity
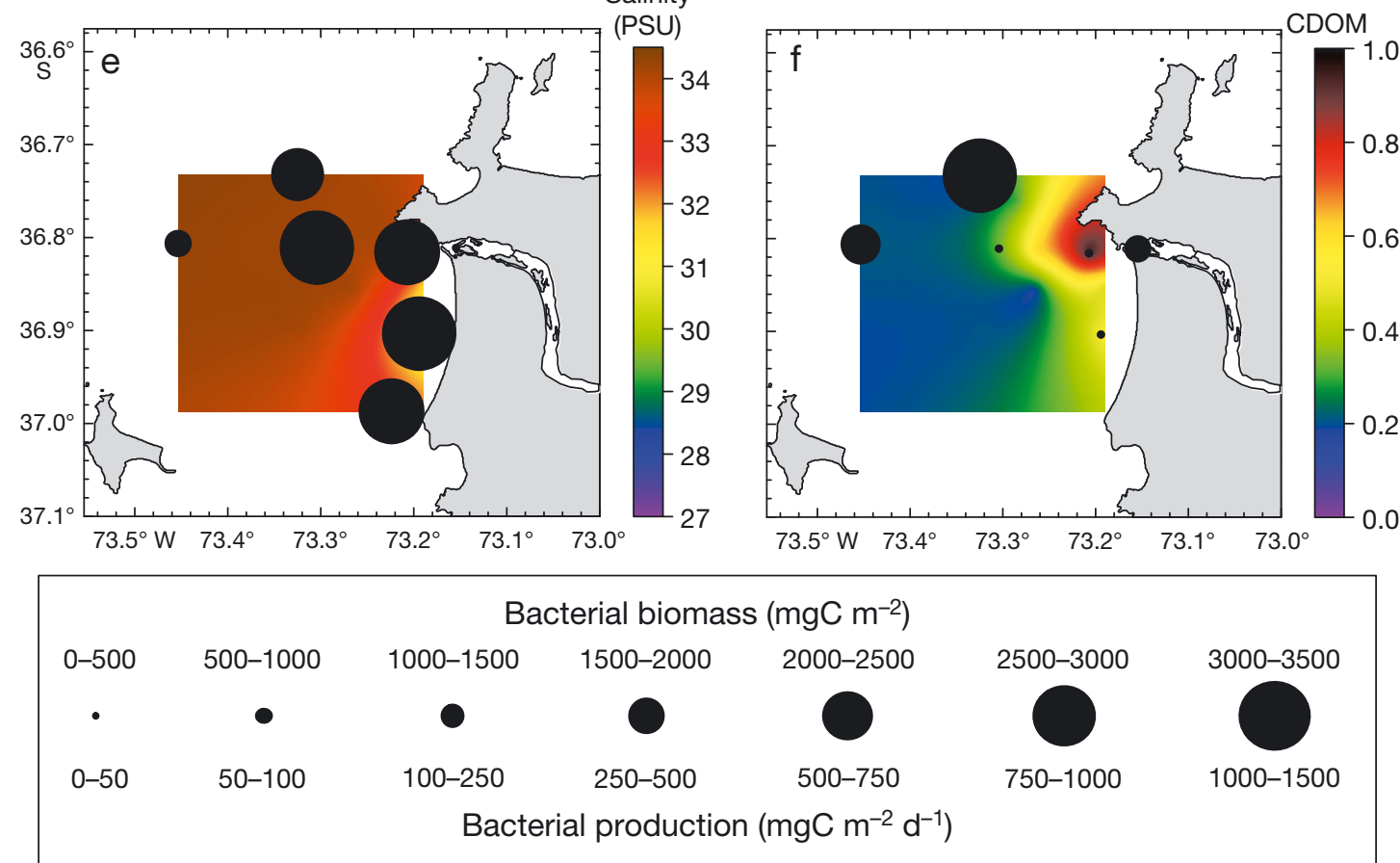

Fig. 7. Spatial distribution of $(a, c, e)$ integrated bacterial biomass and $(b, d, f)$ production in relation to $(a, c, e)$ surface salinity and $(b, d, f)$ colored dissolved organic matter (CDOM, relative units) distribution during $(a, b)$ winter, $(c, d)$ spring, and $(e, f)$ summer. Bacterial production and biomass at the river mouth (Stn 7) were integrated at $2 \mathrm{~m}$ depth. Salinity and CDOM were averaged for the upper $2 \mathrm{~m}$ depth layer 


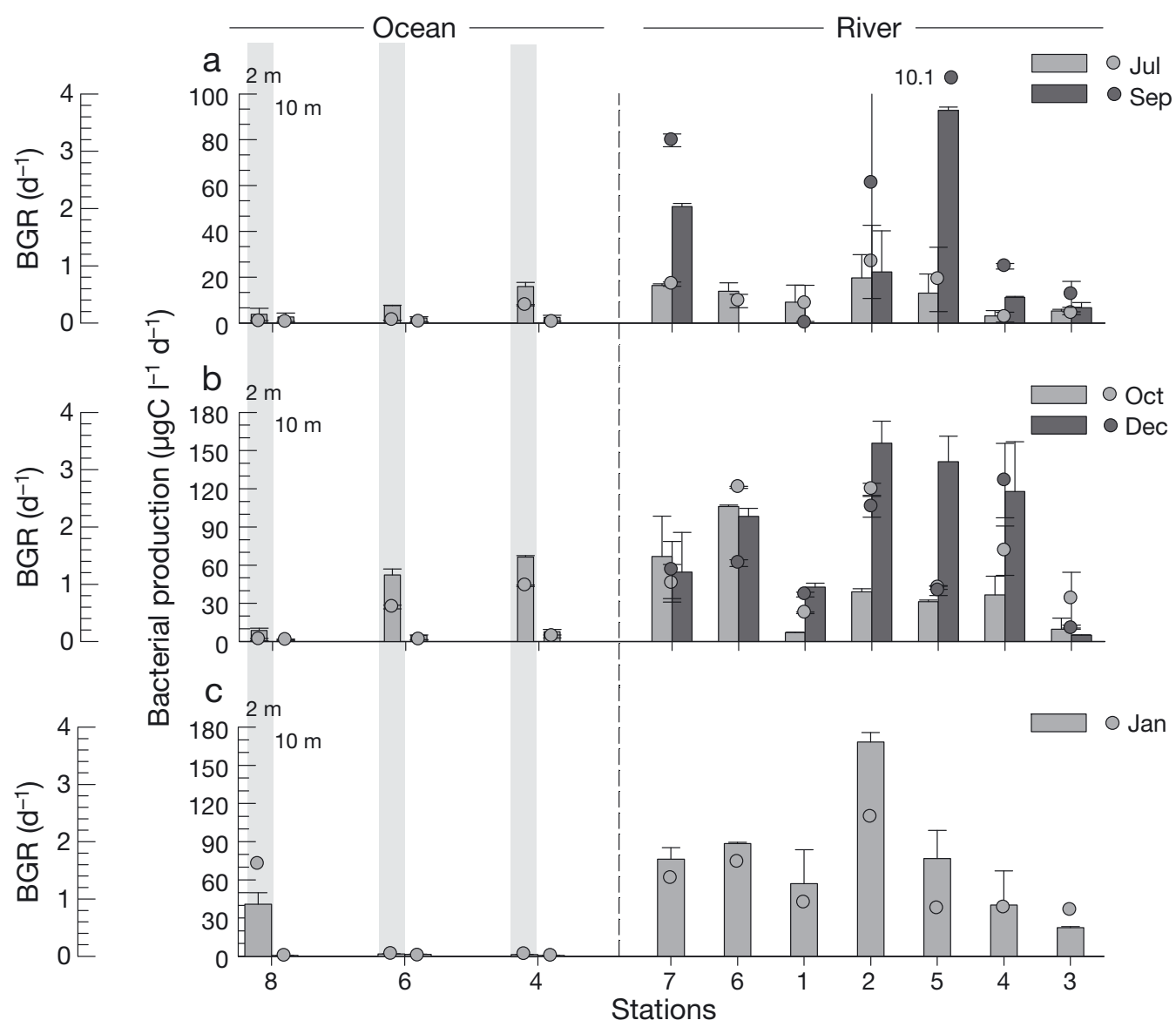

Fig. 8. Mean $( \pm \mathrm{SD})$ bacterial production (bars) and bacterial growth rate (BGR, dots) along the Biobío River and the adjacent coastal ocean (sampling depths: $2 \mathrm{~m}$ [shaded] and $10 \mathrm{~m}$ ) across a 10-station transect, during (a) winter, (b) spring, and (c) summer months. $2 \mathrm{~m}$ and $10 \mathrm{~m}$ represent samples collected at 2 and $10 \mathrm{~m}$ depth during the cruises in the adjacent coastal ocean.

An extreme value of BGR $=10.1$ is included in the same plot in (a). Note: error bars may be so small that not visible

including both freshwater and marine bacterioplankton communities. Our sampling period also involved a gradient of different river flows and upwelling intensities, with the highest river influence during the winter (Fig. 2). Despite the fact that we did not sample over all seasons, we were able to capture some of the seasonal variability in river flow and river plume dynamics in this study area.

Along the river, highest $\mathrm{NO}_{3}{ }^{-}$concentrations were observed (Wilcoxon test, $Z=2.7, \mathrm{p}=0.006$ ) in areas typically affected by high anthropogenic activity, near pulp mill effluents and domestic sewage outflows (Stns 1 and 5), as well as near urbanized areas (Stns 6 and 7). DOC concentrations in the Biobío River were on occasion higher than $600 \mu \mathrm{M}$. They were within the higher range reported for river ecosystems, which suggests that anthropogenic influences could be important in determining its biogeochemical status. A gross comparison of DOC concentrations reported for different rivers worldwide shows a range from $\sim 30$ in clear waters to $\sim 700 \mu \mathrm{M}$ in black water rivers; e.g. Godavari River in India (33 to $191 \mu \mathrm{M}_{i}$ Balakrishna et al. 2006), Tana River in Kenya (108 to $450 \mu M_{i}$ Bouillon et al. 2007), clear and black waters of the Orinoco River Basin in Venezuela (184 to $664 \mu \mathrm{M}_{i}$ Castillo et al. 2004), the Hudson River in the USA (279 to $321 \mu \mathrm{M}_{\text {; }}$ Maranger et al. 2004), and the Mackenzie River in the Arctic (125 to $291 \mu \mathrm{M}$; Vallières et al. 2008). However, during our study, we found no clear correlation between DOC concentration and BA, BB, and/or BP, neither along the river nor in the adjacent coastal ocean.

Our BP estimates along the Biobío River (i.e. 3.1 to 168.4 $\mu \mathrm{g} \mathrm{C}^{-1} \mathrm{~d}^{-1}$ ) were within the mean range reported for other river ecosystems (Table 4a). For instance, Roland \& Cole (1999) reported BP rates between 12 and $240 \mu \mathrm{g} \mathrm{C} \mathrm{l}^{-1} \mathrm{~d}^{-1}$ in the estuarine portion of the Hudson River, whereas Maranger et al. (2004) reported a BP from 24 to $192 \mu g \mathrm{C} \mathrm{l}^{-1} \mathrm{~d}^{-1}$ for the same river, and BP in the Mississippi River ranged from 40 to $110 \mu \mathrm{g} \mathrm{C} \mathrm{l}^{-1} \mathrm{~d}^{-1}$ (Ochs et al. 2009). 


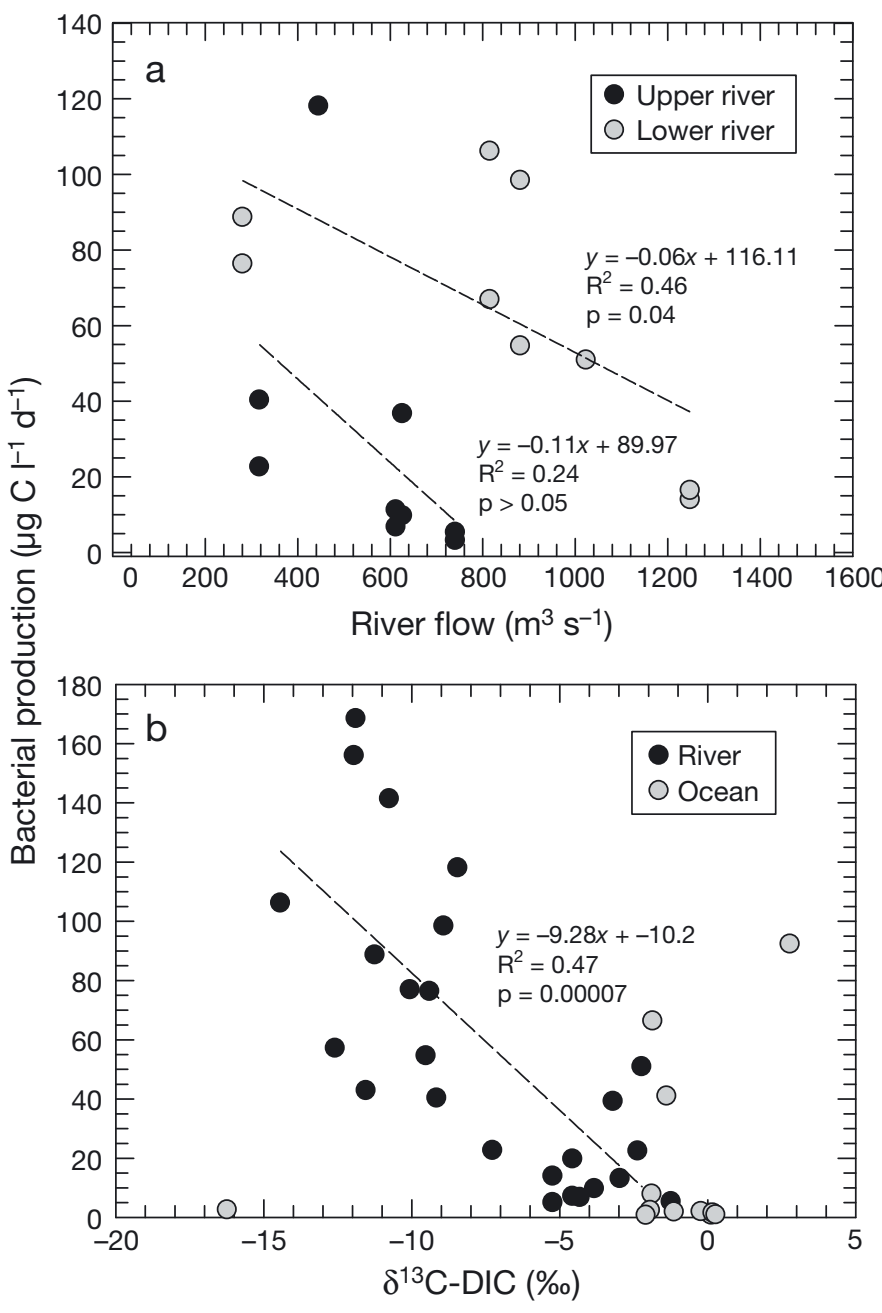

Fig. 9. (a) Relationship between mean bacterial production versus river flow in the upper (Stns 3 and 4 ) and lower (Stns 6 and 7) Biobío River considering different seasons. (b) Relationship between $\delta^{13} \mathrm{C}$-DIC and bacterial production for both river and ocean sampling stations. A significant relationship was only found for river samples

Nevertheless, despite the high BP along the river, $\mathrm{BA}$ and $\mathrm{BB}$ were relatively low in comparison to the adjacent coastal ocean, which resulted in extremely high BGR values (e.g. up to 10.1 in winter, Fig. 8a). The only explanation we found for these findings is the potential effect of protozoan grazing in moving lotic waters, which on occasion might be relatively high. For instance, Carlough \& Meyer (1990) reported that flagellates and ciliates may ingest up to 320 bacteria ind..$^{-1} \mathrm{~h}^{-1}$, with an estimate of $47 \%$ of the water column cleared by protists daily. In addition, bacteria can also be consumed by naked and planktonic amoebas (Lesen et al. 2010) and macroinvertebrates along the river basin (Meyer 1990).
Both in winter and spring, highest BP and BGR were associated with the more anthropogenically influenced areas along the river (Stns 1, 5, 6, and 7; Kruskal-Wallis test $H_{1,32}=14.2 ; \mathrm{p}=0.007$; Fig. 8a,b). The positive correlation between $\mathrm{BA}, \mathrm{BB}$, and production with PC1 suggested that basic parameters such as temperature and conductivity played an important role in bacterial activity. In a detailed analysis of published data, White et al. (1991) found that temperature had a greater impact on BA across different aquatic ecosystems. Nevertheless, the inclusion of $\delta^{13} \mathrm{C}$-DOC in this PC1 suggests that DOC sources also constitute an important factor for bacterial communities. In fact, highest BP and BGR occurred during the period when DOC in river waters were isotopically more depleted $\left(\delta^{13} \mathrm{C}\right.$-DOC from -29 to $\left.-33 \%\right)$. It is evident that not only quantity but also quality of DOC can greatly impact BB (Bott et al. 1984) and BP (Kaplan \& Newbold 1993). It is also well known that, depending on the weight and composition of the DOC, certain molecules might be more refractory than others and consequently be consumed at different rates by the bacterial communities (Ziegler \& Fogel 2003). In our study, the low chl a concentration along the river, as well as the isotopic evidence, indicates that DOC was largely derived from terrestrial sources. The depleted $\delta^{13} \mathrm{C}$ DOC values ( -27 to $-33 \%$ ) during winter and spring suggest that most sources included soil organic matter and fresh vegetation (e.g. Hélie \& Hillaire-Marcel 2006). Although most heavily depleted $\delta^{13} \mathrm{C}$-DOC $(<-30$ to $-33 \%$ ) values were observed in more anthropogenically influenced areas (Stns 5, 2, and 6), the $\delta^{13} \mathrm{C}$-POC measurements taken near domestic sewage and paper mill effluents did not produce such depleted values. Nevertheless, the enrichment of $\delta^{13} \mathrm{C}$ in recipient waters of pulp mill effluent has been demonstrated in other river systems (Wassenaar \& Culp 1996). For a temperate Australian estuary, Oakes et al. (2010) reported an isotopic signature for DOC at a pulp mill outfall typically ranging between -29 and $-30 \%$. However, isotopic measurements do not always provide unequivocal signatures. For instance, weeping willows Salix babylonica are commonly distributed in the mid-portion and lower reaches of the Biobío River, and our $\delta^{13} \mathrm{C}$ measurements showed isotopically characteristic depleted $\delta^{13} \mathrm{C}$ values, between -29 and $-31 \%$ (Table 2). Moreover, phytoplankton production in the lower reaches uses dissolved $\mathrm{CO}_{2}$, which usually has highly variable $\delta^{13} \mathrm{C}$ resulting from organic matter respiration, ranging from -1 to $-15 \%$ (Fig. 9b). Therefore, the isotopic composition of both DOC and POC will depend strongly upon its source of inorganic carbon. Overall, variability in $\delta^{13} \mathrm{C}-\mathrm{POC}$ was small com- 
Table 4. Bacterial production rates reported for several (a) rivers, (b) river plumes, and (c) coastal upwelling areas worldwide

\begin{tabular}{|c|c|c|c|c|}
\hline $\begin{array}{l}\text { Bacterial production } \\
\left(\mu \mathrm{g} \mathrm{C}^{-1} \mathrm{~d}^{-1}\right)\end{array}$ & Period & Method & Location & Source \\
\hline \multicolumn{5}{|l|}{ (a) Rivers } \\
\hline $24-120$ & Annual & ${ }^{3} \mathrm{H}$-thymidine & Meuse River (Belgium) & Servais (1989) \\
\hline $74-426$ & Summer & ${ }^{3} \mathrm{H}$-leucine & James River, Chesapeake, USA & Koepfler et al. (1993) \\
\hline $12-240$ & Annual & ${ }^{3}$ H-leucine & Lower Hudson River & Roland \& Cole (1999) \\
\hline $2.1-9.6$ & Annual & ${ }^{3}$ H-leucine & Orinoco rivers & Castillo et al. (2004) \\
\hline $24-192$ & Annual & ${ }^{3} \mathrm{H}$-leucine & Hudson River, USA & Maranger et al. (2004) \\
\hline $29.9-408$ & Annual & ${ }^{3} \mathrm{H}$-thymidine & Murray River, Australia & Rees et al. (2005) \\
\hline $2.8-9.4$ & Summer & ${ }^{3} \mathrm{H}$-leucine & Mackenzie River, Arctic & Valliéres et al. (2008) \\
\hline $100-110$ & Summer & ${ }^{3} \mathrm{H}$-leucine & Mississippi River, USA & Ochs et al. (2009) \\
\hline $55-60$ & Fall & ${ }^{3} \mathrm{H}$-leucine & Mississippi River, USA & Ochs et al. (2009) \\
\hline $40-45$ & Winter & ${ }^{3} \mathrm{H}$-leucine & Mississippi River, USA & Ochs et al. (2009) \\
\hline $75-85$ & Spring & ${ }^{3}$ H-leucine & Mississippi River, USA & Ochs et al. (2009) \\
\hline $3.1-92.8$ & Winter & ${ }^{14}$ C-leucine & Biobío River, Chile & Present study \\
\hline $5.0-155.9$ & Spring & ${ }^{14} \mathrm{C}$-leucine & Biobío River, Chile & Present study \\
\hline $22.6-168.4$ & Summer & ${ }^{14} \mathrm{C}$-leucine & Biobío River, Chile & Present study \\
\hline \multicolumn{5}{|l|}{ (b) River plume } \\
\hline $0-12$ & Winter & ${ }^{3} \mathrm{H}$-thymidine & Strait of Georgia, Canada & Albright (1983) \\
\hline $5-90$ & Summer & ${ }^{3} \mathrm{H}$-leucine & Mississippi River plume, USA & Chin-Leo \& Benner (1992) \\
\hline $7-32$ & Annual & ${ }^{3} \mathrm{H}$-leucine & Hudson River plume, USA & Ducklow \& Carlson (1992) \\
\hline $0-128$ & Summer/winter & ${ }^{3} \mathrm{H}$-leucine & Fly River plume, Papua & Robertson et al. (1993) \\
\hline $0.74-192$ & Spring/summer & ${ }^{3} \mathrm{H}$-leucine & Mississippi River plume, USA & Amon \& Benner (1998) \\
\hline $2.5-30$ & Winter & ${ }^{14} \mathrm{C}$-leucine & Biobío River, Chile & Present study \\
\hline $7.8-81$ & Spring & ${ }^{14} \mathrm{C}$-leucine & Biobío River, Chile & Present study \\
\hline $0.7-1.3$ & Summer & ${ }^{14}$ C-leucine & Biobío River, Chile & Present study \\
\hline \multicolumn{5}{|l|}{ (c) Upwelling } \\
\hline $4-92$ & Summer & ${ }^{3} \mathrm{H}$-thymidine & Benguela & Lucas et al. (1984) \\
\hline $19.2-33.6$ & Summer & ${ }^{3} \mathrm{H}$-thymidine & Central Chile & McManus \& Peterson (1988) \\
\hline $2.7-22.2$ & Summer & ${ }^{14} \mathrm{C}$-leucine & NW Iberian margin & Barbosa et al. (2001) \\
\hline $0.4-5.7$ & Winter & ${ }^{3} \mathrm{H}$-thymidine & Central Chile & Cuevas et al. (2004) \\
\hline $9.3-52.7$ & Spring & ${ }^{3} \mathrm{H}$-thymidine & Central Chile & Cuevas et al. (2004) \\
\hline
\end{tabular}

pared with $\delta^{13} \mathrm{C}$-DOC variations (Fig. 5), suggesting a more heterogeneous carbon pool in the dissolved fraction, which supported BP along the river. In fact, when we constructed a Keeling plot with field information for a gross estimate of the isotopic composition of the respired carbon source along the river, we obtained an estimate of $\delta^{13} \mathrm{C}$-DIC $=-12.49 \%$, which indicates a clear dominance of terrestrial sources in microbial respiration (Karlsson et al. 2007). Furthermore, highest BP occurred at times when more depleted $\delta^{13} \mathrm{C}$-DIC values were observed (Fig. 9b), which might suggest that highest BP was associated with periods when microbial respiration of terrestrial organic matter was significant. Despite being well known that autochthonous DOC is preferentially utilized for BP over terrestrial DOC (Kritzberg et al. 2004), our results also confirm that in this river ecosystem, autochthonous carbon alone does not support BP. Therefore, the bulk of the terrestrial DOC and POC that the Biobío River delivers to the coastal upwelling area off Concepcion could be partially refractory once it passes through the bacterial respiratory filter of the river.
BP rates in the river plume area and offshore were also within the range reported for other river plumes worldwide (Table 4b). Our BP estimates along the Biobío River plume ranged from 0.7 to $81 \mu \mathrm{g} \mathrm{Cl}^{-1} \mathrm{~d}^{-1}$, with maximum rates during spring. Values (in $\mu \mathrm{g} \mathrm{C}$ $\mathrm{l}^{-1} \mathrm{~d}^{-1}$ ) for other river plume areas are relatively similar, e.g. 5 to 90 (Chin-Leo \& Benner 1992) and 0.7 to 192 for the Mississippi River plume (Amon \& Benner 1998), and from 7 to 32 for the Hudson River plume (Ducklow \& Carlson 1992). Furthermore, BP at the coastal upwelling area off Central Chile measured in other studies, and from other coastal upwelling areas, also fit with our estimations, e.g. from 19.2 to 33.6 in a coastal upwelling site off central Chile (McManus \& Peterson 1988), 4 to 92 in Benguela (Lucas et al. 1984), and 2.7 to $22.2 \mu \mathrm{g} \mathrm{C} \mathrm{l}^{-1} \mathrm{~d}^{-1}$ in the NW Iberian Margin (Barbosa et al. 2001) (Table 4c).

In light of the distribution of $\delta^{13} \mathrm{C}$-DOC along the river-ocean continuum, it was evident that riverine fluxes of organic matter dramatically influenced the composition of DOC in this coastal upwelling area, especially during winter and spring snowmelt period, 
when $\delta^{13} \mathrm{C}$-DOC in the coastal area ranged from -24 to $-28 \%$ (Fig. $4 \mathrm{a}$, b). For oceanic waters, the $\delta^{13} \mathrm{C}$ marine end-member for DOC typically averaged between -20 and $-22 \%$ (e.g. Druffel et al. 1992, Bauer \& Druffel 1998), which implies that using a simple 2end-member mixing model with a $\delta^{13} \mathrm{C}$ of $-29 \%$ for terrigenous DOC and $-21 \%$ for marine DOC, an estimated 38 to $80 \%$ of DOC is allochthonous DOC of terrestrial origin during winter and spring in this coastal area. In contrast, during summer-when river flow was extremely low $\left(<500 \mathrm{~m}^{3} \mathrm{~s}^{-1}\right)$, coastal upwelling events were recurrent, and high phytoplankton production was enhanced (Vargas et al. 2007) - the riverine organic matter made no contribution to carbon pools in this coastal area (Fig. 10).

We found no clear correlation between BP or BGR and chlorophyll, DOC, and/or DOC sources (i.e. measured as $\delta^{13} \mathrm{C}$-DOC). It is common in river plume areas that the classical idea of microbial loop relationships (i.e. algal exudates enhancing BP) can be disrupted due to the input of allochthonous riverine carbon (Findlay et al. 1991). In fact, BA was positively correlated with $\mathrm{PC} 1$, representing variability associated with $\mathrm{PO}_{4}{ }^{3-}$ concentrations and DOC sources $\left(\delta^{13} \mathrm{C}\right.$-DOC). However, highest BP and BGR in the river plume not only implies that riverine allochthonous carbon might be relevant for heterotrophic bacterial activity, but also nutrient and silicate riverine fluxes, and stratification in river plumes might stimulate phytoplankton growth (Dagg et al. 2004) (e.g. spring/summer; Fig. 3h,i). It has been observed in river plume waters that phytoplankton can bloom for periods of 1 to $2 \mathrm{~d}$ and then decline (e.g. by salinity-

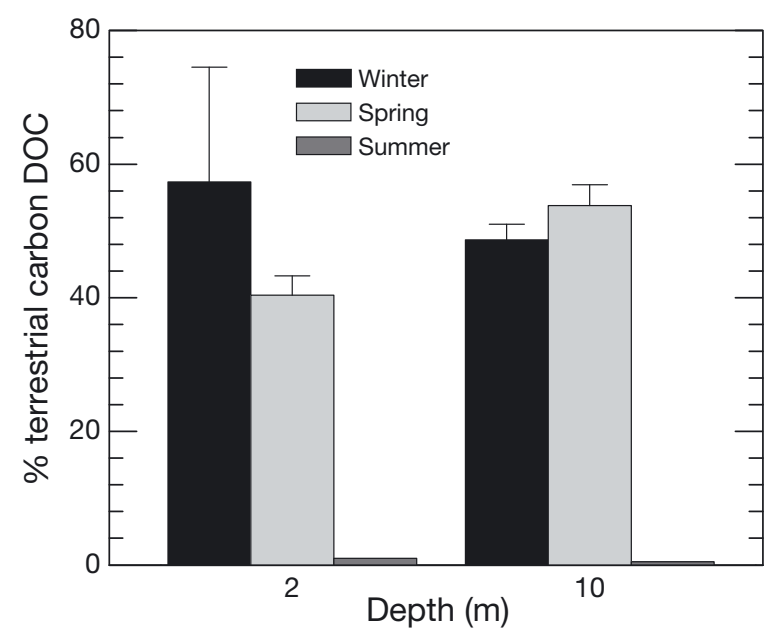

Fig. 10. Average terrestrial contribution (\%) to marine dissolved organic carbon (DOC) at 2 depth levels (2 and $10 \mathrm{~m}$ ) in the adjacent coastal ocean to Biobío River discharge during winter, spring, and summer cruises induced lysis), releasing large amounts of labile DOC (Dagg et al. 2008). In consequence, these results evidence the complex relationship among different environmental factors, including autochthonous versus allochthonous carbon sources that might differentially influence bacterial assemblages in this river-ocean continuum.

As shown in the present study, this river-ocean continuum encompasses a complex spectrum of environmental gradients that each impacts the composition of bacterial communities. Fortunato \& Crump (2011) characterized the bacterioplankton community along a river-to-ocean gradient on the Oregon coast and the Columbia River in Washington (USA), and found that bacterioplankton communities were significantly different between the river and the coastal zone. For the coastal ocean, they even found differences between inshore and offshore communities, probably associated with a physical upwelling regime, which enhances primary production and subsequently increases BP in the communities of nearshore waters.

We draw 2 general conclusions from our study: (1) in a river-ocean continuum, high nutrients and DOC amounts are associated with river sections with the highest anthropogenic activity, stimulating recycling as observed by high BP and BGR; (2) the direct effects of terrestrial DOC discharged by the Biobío River might contribute substantially to carbon fluxes in a productive coastal upwelling area, and a combination of autochthonous (i.e. phytoplankton exudates and/or lysis) and allochthonous (i.e. terrestrial DOC) sources stimulate BP and BGR in river plume areas. Secondary effects associated with the bacterial mineralization of organic carbon and nutrients in surface waters were not examined in this study but are highly relevant issues for future studies, broadening temporal and spatial scales. Considering that DOC might complex toxic trace metals and pollutants which are transported along this river-ocean continuum and occasionally incorporated into coastal food webs via microbial activity, more information regarding the influence of river discharges on biogeochemical and food web processes are needed.

Acknowledgements. We thank the captains and crew of the vessel 'GIMAR' and the RIVOM project team who participated in our coastal cruises and river campaigns (i.e. especially S. Cancino, E. K. Cascales, M. Pavez, D. Donoso, V. Aguilera, and W. San Martin). We also acknowledge J. Cole (Cary Institute for Ecosystem Studies) for valuable comments on an early version of the manuscript. Financial support for this study was fully provided by the FONDECYT Project No. 1095069 to C.A.V. and M.S. 


\section{LITERATURE CITED}

Albright LJ (1983) Influence of river-ocean plumes upon bacterioplankton production of the Strait of Georgia, British Columbia. Mar Ecol Prog Ser 12:107-113

Aminot A, El-Sayed MA, Kerouel R (1990) Fate of natural and anthropogenic dissolved organic carbon in the macro-tidal Elorn estuary. Mar Chem 29:255-275

> Amon RM, Benner R (1998) Seasonal patterns of bacterial abundance and production in the Mississippi River plume and their importance for the fate of enhanced primary production. Microb Ecol 35:289-300

- Balakrishna K, Kumar IA, Srinikethan G, Mugeraya G (2006) Natural and anthropogenic factors controlling the dissolved organic carbon concentrations and fluxes in a large tropical river, India. Environ Monit Assess 122: 355-364

- Barbosa AB, Galväo HM, Mendes PA, Álvarez-Salgado XA, Figueiras FG, Joint I (2001) Short-term variability of heterotrophic bacterioplankton during upwelling off the NW Iberian margin. Prog Oceanogr 51:339-359

> Barra R, Sánchez J, Orrego R, Parra O, Gavilán J (2001) Bioavailability of PAHs in the Biobío River (Chile): MFO activity and biliary fluorescence in juvenile Oncorhynchus mykiss. Chemosphere 45:439-444

> Bauer J, Druffel E (1998) Ocean margins as a significant source of organic matter to the deep open ocean. Nature 392:482-485

Beutler M, Wiltshire $\mathrm{KH}$, Meyer B, Moldaenke $\mathrm{C}$ and others (2002) A fluorometric method for the differentiation of algal populations in vivo and in situ. Photosynth Res 72: 39-53

> Bott TL, Kaplan LA, Kuserk FT (1984) Benthic bacterial biomass supported by streamwater dissolved organic matter. Microb Ecol 10:335-354

> Bouillon S, Dehairs F, Schiettecatte LS, Borges AV (2007) Biogeochemistry of the Tana estuary and delta (northern Kenya). Limnol Oceanogr 52:46-59

Carlough LA, Meyer JL (1990) Rates of protozoan bacterivory in three habitats of a southeastern blackwater river. J N Am Benthol Soc 9:45-53

Castillo MM, Kling GW, Allan JD (2003) Bottom-up controls on bacterial production in tropical lowland rivers. Limnol Oceanogr 48:1466-1475

Castillo MM, Allan JD, Sinsabaugh RL, Kling GW (2004) Seasonal and interannual variation of bacterial production in lowland rivers of the Orinoco basin. Freshw Biol 49:1400-1414

Chin-Leo G, Benner R (1992) Enhanced bacterioplankton production and respiration at intermediate salinities in the Mississippi River plume. Mar Ecol Prog Ser 87: 87-103

Clayton TD, Byrne RH (1993) Spectrophotometric seawater pH measurements: total hydrogen ion concentration scale calibration of $m$-cresol purple and at sea results. Deep-Sea Res 40:2315-2329

Cole JJ, Caraco NF (2001) Carbon in catchments: connecting terrestrial carbon losses with aquatic metabolism. Mar Freshw Res 52:101-110

> Cole JJ, Findlay S, Pace ML (1988) Bacterial production in fresh and saltwater ecosystems: a cross-system overview. Mar Ecol Prog Ser 43:1-10

Cole JJ, Prairie YT, Caraco NF, McDowell WH and others (2007) Plumbing the global carbon cycle: integrating inland waters into the terrestrial carbon budget. Eco- systems 10:172-184

> Cuevas LA, Daneri G, Jacob B, Montero P (2004) Microbial abundance and activity in the seasonal upwelling area off Concepción $\left(\sim 36^{\circ} \mathrm{S}\right)$, central Chile: a comparison of upwelling and non-upwelling conditions. Deep-Sea Res II 51:2427-2440

Dagg MJ, Benner R, Lohrenz S, Lawrence D (2004) Transformation of dissolved and particulate materials on continental shelves influenced by large rivers: plume processes. Cont Shelf Res 24:833-858

Dagg MJ, Bianchi T, McKee B, Powell R (2008) Fates of dissolved and particulate materials from the Mississippi river immediately after discharge into the northern Gulf of Mexico, USA, during a period of low wind stress. Cont Shelf Res 28:1443-1450

Del Giorgio PA, Pace ML, Fischer D (2006) Relationship of bacterial growth efficiency to spatial variation in bacterial activity in the Hudson River. Aquat Microb Ecol 45: 55-67

> Druffel ERM, Williams PM, Bauer JE, Ertel J (1992) Cycling of dissolved and particulate organic matter in the open ocean. J Geophys Res 97:15639-15659

> Ducklow HW, Carlson CA (1992) Oceanic bacterial production. Adv Microb Ecol 12:113-180

> Ducklow H, Kirchman D (1983) Bacterial dynamics and distribution during a spring diatom bloom in the Hudson River plume, USA. J Plankton Res 5:333-355

> Edwards RT, Meyer JL (1986) Production and turnover of planktonic bacteria in two southeastern blackwater rivers. Appl Environ Microbiol 52:1317-1323

> Findlay S, Pace ML, Lints D, Cole JJ (1991) Weak coupling of bacterial and algal production in a heterotrophic ecosystem: the Hudson River estuary. Limnol Oceanogr 36: 268-278

> Focardi S, Fossi C, Leonzio C, Corsolini S, Parra O (1996) Persistent organochlorine residues in fish and water birds from the Biobío River, Chile. Environ Monit Assess 43:73-92

Fortunato CS, Crump BC (2011) Bacterioplankton community variation across river to ocean environmental gradients. Microb Ecol 62:374-382

Fuhrman JA, Azam F (1982) Thymidine incorporation as a measure of heterotrophic bacterioplankton production in marine surface waters: evaluation and field results. Mar Biol 66:109-120

> Hedges JI, Keil RG, Benner R (1997) What happens to terrestrial organic matter in the ocean? Org Geochem 27: 195-212

Hélie JF, Hillaire-Marcel C (2006) Sources of particulate and dissolved organic carbon in the St Lawrence River: isotopic approach. Hydrol Processes 20:1945-1959

Hernández KL, Quiñones RA, Daneri G, Helbling EW (2006) Effects of solar radiation on bacterioplankton production in the upwelling system off central-southern Chile. Mar Ecol Prog Ser 315:19-31

> Judd KE, Crump BC, Kling GW (2006) Variation in dissolved organic matter controls bacterial production and community composition. Ecology 87:2068-2079

Kaplan LA, Newbold JD (1993) Biogeochemistry of dissolved organic carbon entering streams. In: Ford TE (ed) Aquatic microbiology: an ecological approach. Blackwell Scientific, Oxford, p 139-165

Karlsson J, Jansson M, Jonsson A (2007) Respiration of allochthonous organic carbon in unproductive forest lakes determined by the Keeling plot method. Limnol 
Oceanogr 52:603-608

Karrasch B, Parra O, Cid H, Mehrens M and others (2006) Effects of pulp and paper mill effluents on the microplankton and microbial self-purification capabilities of the Biobío River, Chile. Sci Total Environ 359:194-208

Koepfler ET, Kator HI, Wetzel RL, Haas LW, Webb KL (1993) Spatial and temporal bacterioplankton dynamics during destratification of the James River estuary, Virginia, USA. Mar Ecol Prog Ser 102:229-244

Kritzberg ES, Cole JJ, Pace ML, Granéli W, Bade DL (2004) Autochthonous versus allochthonous carbon sources of bacteria: results from whole-lake ${ }^{13} \mathrm{C}$ addition experiments. Limnol Oceanogr 49:588-596

Lee S, Fuhrman JA (1987) Relationships between biovolume and biomass of naturally derived marine bacterioplankton. Appl Environ Microbiol 53:1298-1303

Lesen AE, Juhl AR, Anderson OR (2010) Heterotrophic microplankton in the lower Hudson River Estuary: potential importance of naked, planktonic amebas for bacterivory and carbon flux. Aquat Microb Ecol 61:45-56

Lucas MI, Painting SJ, Muir DG (1984) Estimates of carbon flow through bacterioplankton in the Benguela upwelling region based on ${ }^{3} \mathrm{H}$-thymidine incorporation and predator-free incubations. GI-RBAM, Deuxième Colloque International de Bactériologie marine, CNR, IFREMER. Actes Colloq 3:375-383

Maranger RJ, Pace ML, del Giorgio PA, Caraco NF, Cole JJ (2004) Longitudinal spatial patterns of bacterial production and respiration in a large-river-estuary: implications for ecosystems carbon consumption. Ecosystems 8:1-14

McManus GB, Peterson WT (1988) Bacterioplankton production in the nearshore zone during upwelling off central Chile. Mar Ecol Prog Ser 43:11-17

Meyer JL (1990) A blackwater perspective on riverine ecosystems. Bioscience 40:643-651

> Meyers PA (1997) Organic geochemical proxies of paleoceanographic, paleolimnologic, and paleoclimatic processes. Org Geochem 27:213-250

Murphy J, Riley JP (1962) A modified single solution method for the determination of phosphate in natural waters. Anal Chim Acta 27:31-36

Nagata T, Okamoto K (1988) Filtering rates on natural bacteria by Daphnia longispina and Eodiaptomus japonicus in Lake Biwa. J Plankton Res 10:835-850

> Nezlin NP, DiGiacomo PM (2005) Satellite ocean color observations of stormwater runoff plumes along the San Pedro Shelf (southern California) during 1997-2003. Cont Shelf Res 25:1692-1711

Oakes JM, Eyre BD, Ross DJ, Turner SD (2010) Stable isotopes trace estuarine transformations of carbon and nitrogen from primary- and secondary-treated paper and pulp mill effluent. Environ Sci Technol 44:7411-7417

> Ochs C, Capello HE, Pongruktham O (2009) Bacterial production in the Lower Mississippi River: importance of suspended sediment and phytoplankton biomass. Hydrobiologia 637:19-31

Opsahl S, Benner R (1997) Distribution and cycling of terrigenous dissolved organic matter in the ocean. Nature 386:480-482

Pace ML, Cole JJ (1996) Regulation of bacteria by resources and predation tested in whole-lake experiments. Limnol Oceanogr 41:1448-1460

Parsons TR, Maita Y, Lalli CM (1984) Manual of chemical and biological methods for seawater analysis. Pergamon Press, Oxford
Porter KG, Feig YS (1980) The use of DAPI for identifying and counting aquatic microflora. Limnol Oceanogr 25: 943-948

Raymond PA, Bauer JE (2001) Riverine export of aged terrestrial organic matter to the North Atlantic Ocean. Nature 409:497-500

$>$ Rees GN, Beattie G, Bowen PM, Hart BT (2005) Heterotrophic bacterial production in the lower Murray River, south-eastern Australia. Mar Freshw Res 56:835-841

Reimann C, Filzmoser P, Garrett R, Dutter R (2008) Statistical data analyses explained: applied environmental statistics with R. John Wiley \& Sons, Chichester

Robertson A, Daniel P, Dixon P, Alongi D (1993) Pelagic biological processes along a salinity gradient in the Fly delta and adjacent river plume (Papua New Guinea). Cont Shelf Res 13:205-224

$>$ Roland F, Cole JJ (1999) Regulation of bacterial growth efficiency in a large turbid estuary. Aquat Microb Ecol 20: 31-38

> Sánchez GE, Pantoja S, Lange CB, González HE, Daneri G (2008) Seasonal changes in particulate biogenic and lithogenic silica in the upwelling system off Concepción $\left(\sim 36^{\circ} \mathrm{S}\right)$, Chile, and their relationship to fluctuations in marine productivity and continental input. Cont Shelf Res 28:2594-2600

Servais P (1989) Bacterioplanktonic biomass and production in the river Meuse (Belgium). Hydrobiologia 174:99-110

Simon M, Azam F (1989) Protein content and protein synthesis rates of planktonic marine bacteria. Mar Ecol Prog Ser 51:201-213

Sinsabaugh RL, Findlay S, Franchini P, Fisher D (1997) Enzymatic analysis of riverine bacterioplankton production. Limnol Oceanogr 42:29-38

Smith RL (1968) Upwelling. Oceanogr Mar Biol Annu Rev 6: $11-46$

Sobarzo M, Bravo L, Donoso D, Garcés-Vargas J, Schneider W (2007) Coastal upwelling and seasonal cycles that influence the water column over the continental shelf off central Chile. Prog Oceanogr 75:363-382

> Troncoso VA, Daneri G, Cuevas LA, Jacob B, Montero P (2003) Bacterial carbon flow in the Humboldt Current System off Chile. Mar Ecol Prog Ser 250:1-12

- Vallières C, Retamal L, Ramlal P, Osburn CL, Vincent WF (2008) Bacterial production and microbial food web structure in a large arctic river and the coastal Arctic Ocean. J Mar Syst 74:756-773

> Van Heemst JDH, Megens L, Hatcher PG, de Leeuw JW (2000) Nature, origin and average age of estuarine ultrafiltered dissolved organic matter as determined by molecular and carbon isotopic characterization. Org Geochem 31:847-857

- Van Looij A, Riemann B (1993) Measurements of bacterial production in coastal marine environments using leucine: application of a kinetic approach to correct for isotope dilution. Mar Ecol Prog Ser 102:97-104

> Vargas CA, González HE (2004) Plankton community structure and carbon cycling in a coastal upwelling system. I. Bacteria, microprotozoans and phytoplankton in the diet of copepods and appendicularians. Aquat Microb Ecol 34:151-164

> Vargas CA, Martínez R, Cuevas L, Pavez M and others (2007) The relative importance of microbial and classical food webs in a highly productive coastal upwelling area. Limnol Oceanogr 52:1495-1510

> Wang M, Shi W (2007) The NIR-SWIR combined atmos- 
pheric correction approach for MODIS ocean color data processing. Opt Express 15:15722-15733

Wassenaar LI, Culp JM (1996) The use of stable isotopic analyses to identify pulp mill effluent signatures in riverine food webs. In: Servos MR, Munkittrick KR, Carey JH, Van Der Kraak GJ (eds) Environmental fate and effects of pulp and paper mill effluents. St. Lucie Press, Delray Beach, FL, p 413-423

Editorial responsibility: Craig Carlson,

Santa Barbara, California, USA
White PA, Kalff J, Rasmussen JB, Gasol JM (1991) The effect of temperature and algal biomass on bacterial production and specific growth rate in freshwater and marine habitats. Microb Ecol 21:99-118

Ziegler SE, Fogel ML (2003) Seasonal and diel relationships between the isotopic composition of dissolved and particulate organic matter in freshwater ecosystems. Biogeochemistry 64:22-52

Submitted: December 8, 2011; Accepted: November 22, 2012 Proofs received from author(s): February 2, 2013 